\title{
GIVETIAN BRACHIOPOD FAUNAS OF THE PALENTIAN DOMAIN (N SPAIN)
}

\author{
Jenaro L. GARCÍA-ALCALDE \\ Departmento de Geología (Paleontología), Universidad de Oviedo, c/ Jesús \\ Arias de Velasco, s/n, 33005 Oviedo, Asturias, Spain. \\ email: jalcalde@geol.uniovi.es
}

García-Alcalde, J.L. 2010. Givetian Brachiopod faunas of the Palentian Domain (N Spain). [Braquiópodos del Givetiense del Dominio Palentino (Norte de España).] Revista Española de Paleontología, 25 (1), 43-69, ISSN 0213-6937

\begin{abstract}
The origin, evolution, structural and stratigraphical features of the Palentian Domain (Cantabrian Mountains, N Spain) are summarily described. The boundaries of the Givetian succession (ca. $40 \mathrm{~m}$ thick) in that area are established from previously known conodont and ammonoid data. The base of the Givetian is situated in the upper part of the Gustalapiedra Formation, at the base of the La Pedrosa Member. The upper Givetian boundary is situated at the top of the lower calcareous interval of the Cardaño Formation. Middle Devonian brachiopods are scarce in the Palentian Domain. In fact no Givetian form has been cited in the area until now. In this paper nine brachiopod species (three new) of the Givetian interval are described and figured: Skenidium cf. polonicum, Rhyssochonetes aff. douvillei, Prodavidsonia havliceki n. sp., Bifida aff. lepida, Ambothyris cf. infima, "Pyramidalia" palentina n. sp., Cingulodermis sotoana n. sp., Parastringocephalus cf. dorsalis, and Ense andrea. The genera Skenidium, Rhyssochonetes, Ambothyris, Cingulodermis, Parastringocephalus, and Ense are cited in Spain for the first time. Parastringocephalus is moreover the first stringocephaline found in Palencia. "Pyramidalia" palentina $\mathrm{n}$. sp. is an impunctate form provided with a nearly complete symphytium, a delthyrial plate and short dental plates; these features separate the genus Pyramidalia both from Cyrtinaella and Thomasaria with which the former genus has sometimes been synonymised. Near the base of the Cardaño Fm. a coquina with thousands of specimens of Ense andrea has been found. This coquina could represent the area of the famous "Pumilio" Event, described previously from Germany, France and North Africa. The Spanish Ense andrea specimens are endopunctate and a sectioned shell shows a centronelliform brachidium. The terebratulid nature of the species is certain and the features referred to above and the external morphology of the shell are closer to the Subfamily Adreninae than to the Subfamily Mutationellinae where Ense had previously been tentatively included.
\end{abstract}

Keywords: brachiopods, Givetian, Stratigraphy, Palentian Domain (N Spain).

\section{RESUMEN}

Se describen brevemente el origen y evolución, así como las características estructurales y estratigráficas, del Dominio Palentino (Cordillera Cantábrica, N de España). Se precisan los límites de la sucesión Givetiense (con un espesor aproximado de $40 \mathrm{~m}$ ) en el área, basándose en datos previos de conodontos y ammonoideos; su base se sitúa en la parte alta de la Formación Gustalapiedra, al comienzo del Miembro La Pedrosa y su techo hacia la parte alta del paquete calcáreo basal de la Formación Cardaño. Los braquiópodos son escasos en el Devónico Medio del Dominio Palentino. De hecho hasta hoy nunca se habían citado formas del Givetiense. Aquí se describen y figuran, nueve taxones del intervalo Givetiense (tres nuevos): Skenidium cf. polonicum, Rhyssochonetes aff. douvillei, Prodavidsonia havliceki n. sp., Bifida aff. lepida, Ambothyris cf. infima, "Pyramidalia" palentina n. sp., Cingulodermis sotoana n. sp., Parastringocephalus cf. dorsalis y Ense andrea. Los géneros Skenidium, Rhyssochonetes, Ambothyris, Cingulodermis, Parastringocephalus y Ense, se citan por primera vez en España. Parastringocephalus es, además, el primer estringocefalino encontrado en Palencia. "Pyramidalia" palentina n. sp. tiene concha impuntuada, un symphytium casi completo, placa deltirial y placas dentales cortas en la valva ventral, características que parecen alejar el género Pyramidalia tanto de Cyrtinaella como de Thomasaria con los cuales fue sinonimizado. Casi en la base de la Fm. Cardaño se descubrió una lumaquela compuesta por millares de ejemplares de Ense andrea, que parece representar en el área el conocido Evento "Pumilio", descrito hasta ahora en Alemania, Francia y Norte de África; el estado del material permitió poner en evidencia la pre- 
sencia de endopuntos y de un braquidio centroneliforme, lo que asegura la naturaleza terebratúlida de la especie; dichas características y la morfología externa de la concha son más propias de la Subfamilia Adreninae, que de la Subfamilia Mutationellinae, donde tentativamente fue incluido el género Ense.

Palabras clave: braquiópodos, Givetiense, Estratigrafía, Dominio Palentino (Norte España).

\section{INTRODUCTION}

The Palentian Domain (Brouwer, 1964) (Fig. 1) (more or less equivalent to the Pisuerga-Carrión Province, Julivert, 1971) is considered herein as a predominantly Silurian-Lower Carboniferous allochthonous unit, that was emplaced in its present setting upon the Cantabrian Zone (Lotze, 1945), coming from the southwestern-located WestAsturian-Leonian Zone (Lotze, 1945) (references in GarcíaAlcalde et al., 1990a, b, 2002; Alonso et al. 2009). According to Henn \& Jahnke (1984) the Palentian Domain would be the offshore southern continuation of the Asturo-Leonian platform. By the end of Namurian-Westphalian A time the so-called Palentian nappes were thrust over the Valsurvio region (Valsurvio Dome) (Fig. 1), a sub-unit of the AsturoLeonian Domain (Lotze, 1945; Alonso et al., 2009), and they underwent gravitational collapse to form rootless units in the Pisuerga-Carrión area, resting on relatively autochthonous synorogenic Carboniferous rocks. Later on, they were overprinted by strong Variscan deformation (see Rodríguez-Fernández, 1994, García-Alcalde et al., 2002, and Alonso et al., 2009, for a complete bibliography).

The greater part of the Palentian Devonian originated in distal shelf environments corresponding to the offshore

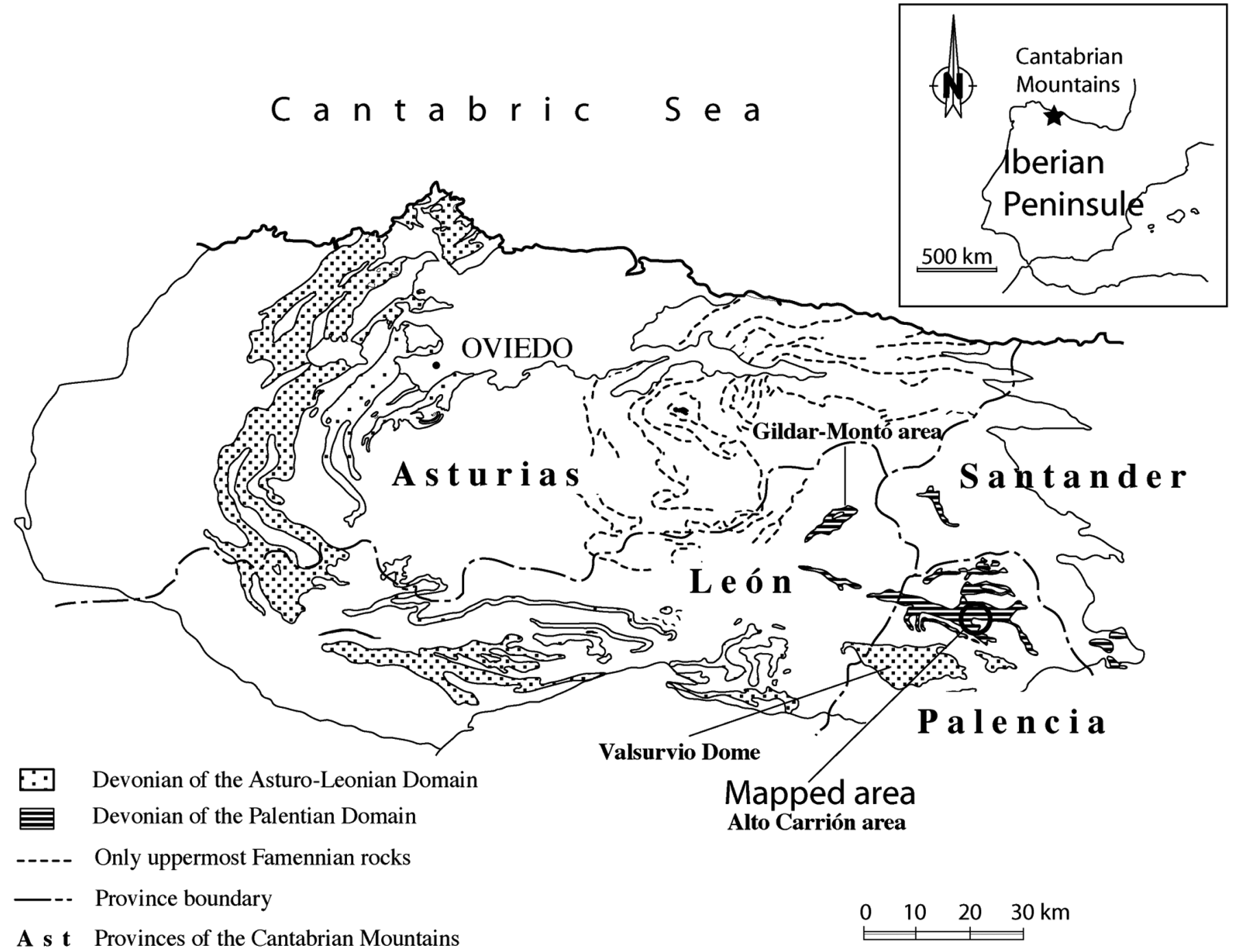

Figure 1. The Devonian in the Cantabrian Mountains. Shown are location of the areas mentioned in the text. 


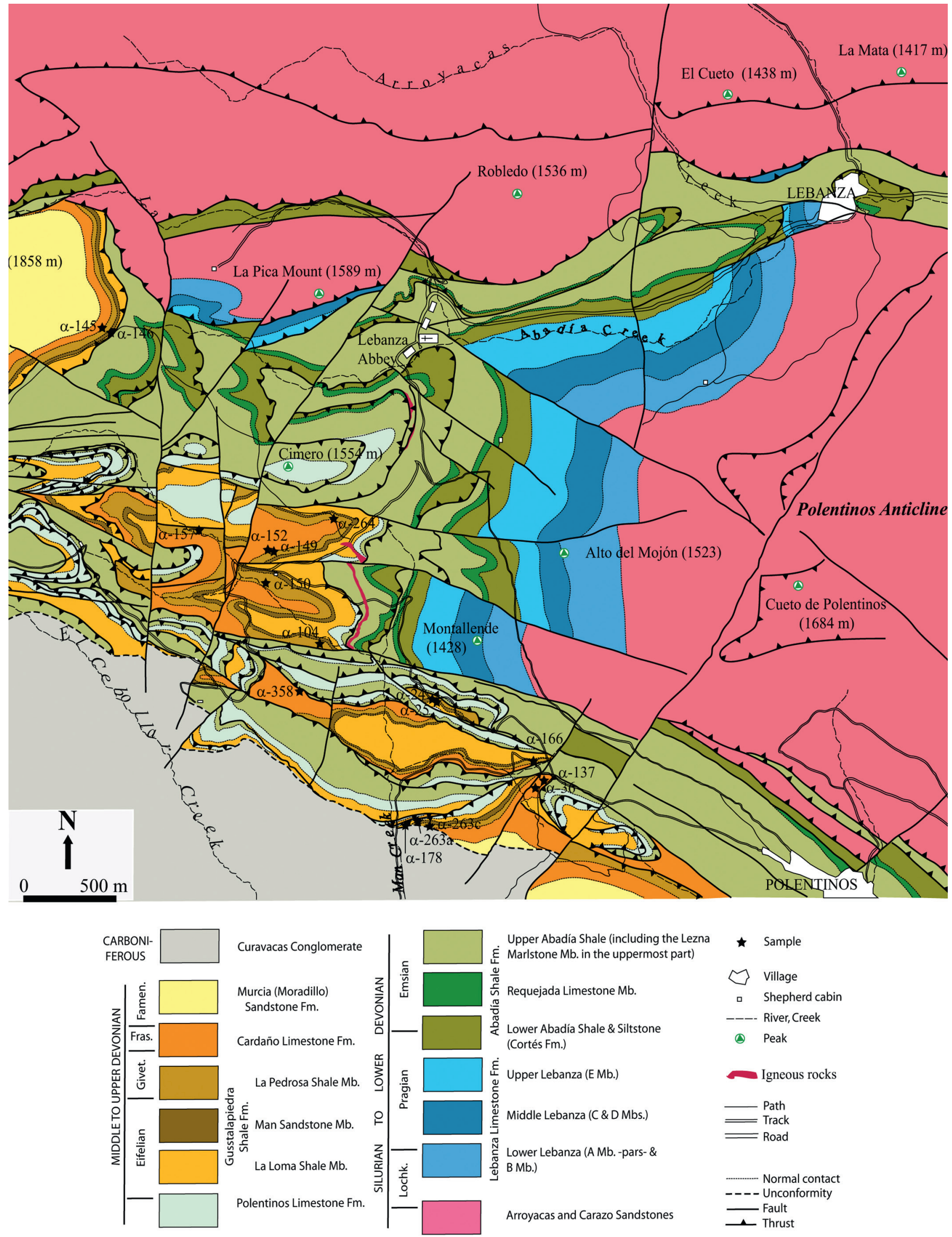

Figure 2. Simplified geological map of the Polentinos anticline-Man antiformal stack area (mapping after impublished data by the author). 


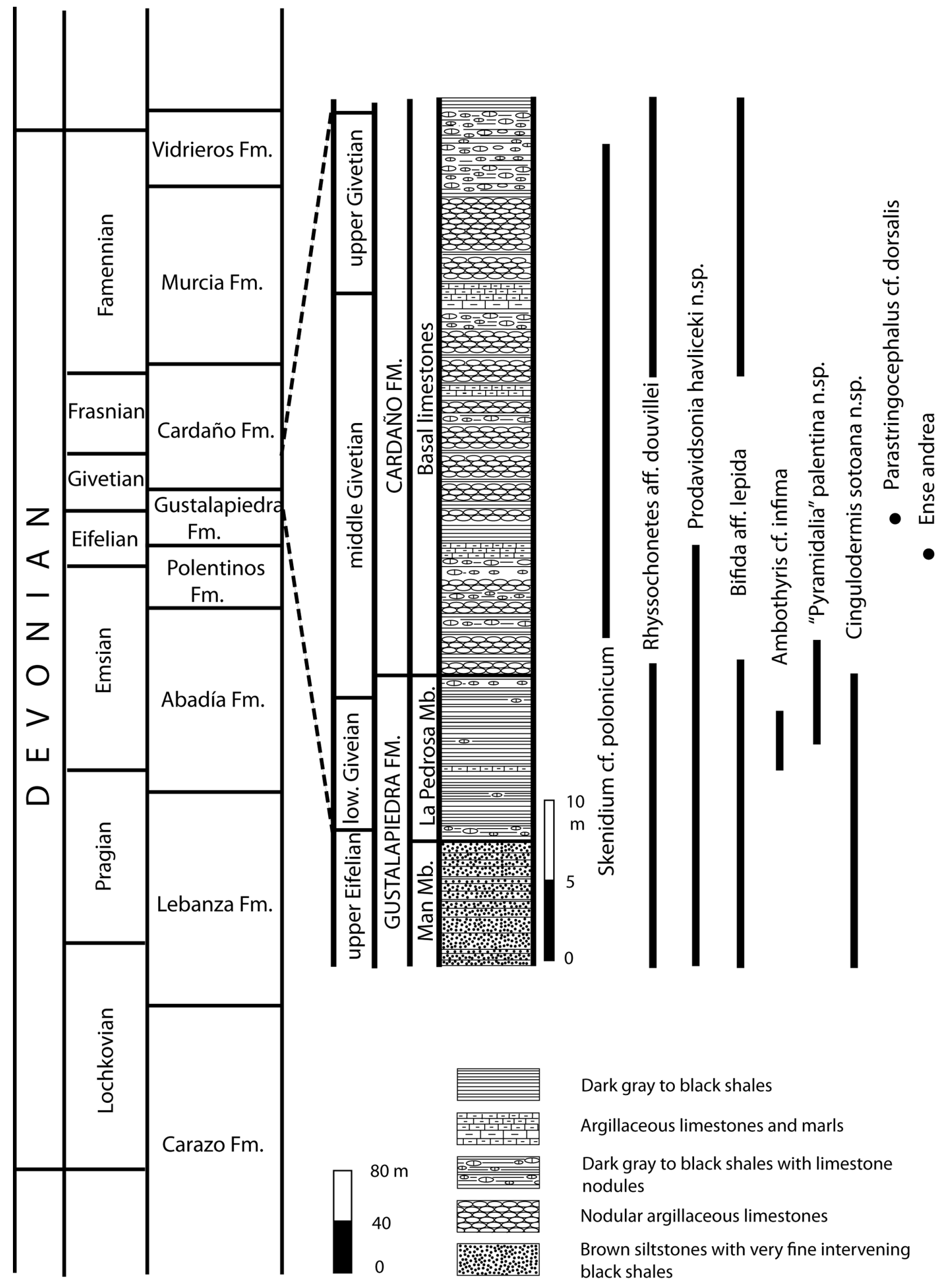

Figure 3. Stratigraphy of the Devonian of the Palentian Domain. Detail of the Givetian stratigraphy with the vertical distribution of the species studied herein. 
pelagic realm. But differentiation from the more neritic Asturo-Leonian Devonian proceeded steadily from Emsian time onwards, although episodic "asturoleonian"like neritic facies intervals occur at different levels of the post-Emsian Palentian succession (Henn \& Jahnke, 1984).

Offshore Palentian facies are very condensed compared to nearshore Asturo-Leonian. The entire Asturo-Leonian Devonian succession is more than twice as thick as the Palentian (ca. $2000 \mathrm{~m}$ for the former, ca. $800 \mathrm{~m}$ for the latter) (Jahnke et al., 1983; García-Alcalde et al., 2002). And, particular time intervals and Stages show even greater unbalanced sedimentation rates (i.e. 13:1 for the Emsian/ Eifelian transition, Ellwood et al., 2006; more than 8:1 for the Givetian, herein).

\section{STRATIGRAPHY}

The stratigraphy of the Palentian Devonian is extremely difficult to discern, because of strong tectonics involving numerous thrust superpositions at a vast array of scales (from centimetres to kilometres) fueled by the plastic nature of the very fine-grained mudstone and shaly rocks usual for the zone, further complicated by Alpine folding and faulting (Fig. 2). In consequence, there exist marked interpretative differences among authors that have worked in the region concerning the thicknesses and naming of stratigraphical Devonian units (i.e. compare thicknesses assigned to the Givetian by Veen, 1985; Henn, 1985; Jahnke et al., 1983; García-Alcalde et al., 1988; Gozalo et al., 1990, and Rodríguez-Fernández, 1994). In this paper we adopt the stratigraphic bases proposed by García-Alcalde et al. (1988) (thickness of Givetian ca. $40 \mathrm{~m}$ ), updated in García-Alcalde et al. (2002), with minor modifications and additions, for the most part related to cartographic utility (Fig. 2). The main modifications are (Fig. 3):

a) The three-fold division of the Lebanza, Abadía, and Gustalapiedra Formations,

b) The acceptance of the name La Pedrosa Member (Henn, 1985) for the upper part of the Gustalapiedra Fm. above the sandstones of the Man Member. The name La Loma Member for the Gustalapiedra Fm. succession below the Man $\mathrm{Mb}$. is only provisionally accepted herein because it lacks a definite top in its type-locality (Henn, 1985, Fig. 16).

c) The inclusion in the La Loma Member of the nodular, dark gray, lime mudstones that occur just below the sandstones of the Man Mb. s.s. in the upper third of the Gustalapiedra Fm. (vs. García-Alcalde et al., 1990a, b; Truyols-Massoni et al., 1990; Gozalo et al., 1990; Rodríguez-Fernández, 1994; who assigned these layers to the Man Mb. itself).

Most Devonian Palentian lithostratigraphic units have been named after localities situated at or near the mapped area (Fig. 2) (i.e. the Carazo, Lebanza, Abadía, and Polenti- nos Fms, and the Requejada and Man Mbs) Still, nearly all the Middle-Upper Devonian units have been defined further west, in the Cardaño de Arriba-Pico Murcia area (i.e. the Gustalapiedra, Cardaño, Murcia, and Vidrieros Fms), and further south, south of the Requejada (Vañes) Reservoir (i.e. the Loma Mb.) (see Rodríguez-Fernández, 1994).

Guide-fossils for precise correlations are scarce and their relative stratigraphic positions barely known. Conodonts have been determined mainly by Adrichem-Boogaert (1965, 1967), Mouravieff (in Lobato, 1977), Jahnke et al. (1983), and Henn (1985). These data are, however, obscure because of the strong tectonization of the zone, and they need a complete and profound updating. Ammonoids (Kullmann, 1960, 1964; Henn, 1985; Montesinos \& Henn, 1986; Montesinos, 1987a, b, 1990; Montesinos in GarcíaAlcalde et al., 1990a, b; Montesinos \& Sánz-López, 1997, 1999), and trilobites (Smeenk, 1983) are also spotty and the specimens are usually badly preserved. Dacryoconarids and homoctenids (Truyols-Massoni, 1989, 1999; TruyolsMassoni in García-Alcalde et al., 1990a, b) and entomozoids (Gozalo \& Sánchez de Posada, 1998) are abundant at some levels, but they do not provide much precise chronostratigraphic indication. The distribution of brachiopods is also sparse, and their diversity and abundance is always very low except in special cases as will be reported later.

The Eifelian/Givetian boundary in the Palentian domain could roughly be traced in the lower part of La Pedrosa Mb. (Truyols-Massoni et al., 1990; García-Alcalde \& Soto, 1999) (Fig. 3). Indeed, Eifelian ammonoid forms such as Cabrieroceras crispiforme, C. ougartense, Subanarcestes macrocephalus, Pinacites, and Fidelites, disappear either immediately below or just above the Man $\mathrm{Mb}$. (Montesinos in Truyols-Massoni et al., 1990) perhaps in the Polygnathus ensensis conodont Zone (Henn, 1985). On the other hand, uppermost Eifelian to Givetian forms such as Wedekindella, Holzapfeloceras, Agoniatites costulatus, Parodiceras, and Tornoceras, occur in the La Pedrosa Mb. itself (Montesinos in Truyols-Massoni et al., 1990; GarcíaAlcalde, 1999; García-Alcalde \& Soto, 1999), probably in the Lower P. varcus conodont Zone (although clear conodont index-forms of the named zones are definitely lacking therein) (compare with MD IIA/B faunas in Becker \& House, 1994). The dacryoconarid Nowakia otomari straddles the Man Member (Truyols-Massoni in Truyols-Massoni et al., 1990). Among the brachiopods, an upper Eifelian brachiopod faunal assemblage, mainly characterized by the occurrence of Paraplicanoplia infima, Holynetes cf. holynensis, Prodavidsonia havliceki n. sp. and Palentiella palentina occurs just below the Man Mb. (García-Alcalde \& Truyols-Massoni, 2000; García-Alcalde, 2009). Several brachiopod forms also straddle the Man Mb. (i.e. Cingulodermis sotoana n. sp., Rhyssochonetes aff. douvillei, Prodavidsonia havliceki n. sp., Bifida aff. lepida) and are associated usually with younger forms, such as "Pyramidalia" palentina n. sp., Ambothyris cf. infima, and Skenid- 
ium cf. polonicum, in the uppermost part of the La Pedrosa $\mathrm{Mb}$. in beds of probable lower to middle Givetian age. On the other hand, the litho-, bio- and magnetosusceptibility events that occur near the Man Mb. (both below and immediately above) are related to the so-called Kačak-Otomari Event (Truyols-Massoni et al., 1990; García-Alcalde et al., 2001; Ellwood, pers. com. 2009 on MSEC interpretation), an uppermost Eifelian global event recorded worldwide.

In turn, the Givetian/Frasnian boundary would be placed in an undetermined level of the Cardaño Formation, probably in the upper part of the basal limestones of the formation (Fig. 3). These basal limestones have yielded middle to upper Givetian conodonts (Middle P. varcus to
Lowermost $P$. asymmetricus or Lower Mesotaxis falsiovalis Zones), such as Ozarkodina semialternans, Icriodus eslaensis, Polygnathus ensensis, P. xylus, $P$. varcus, $P$. ovatinodosus, $P$. cristatus, Schmidthognathus hermanni, and $S$. wittekindti, Palmatolepis disparilis, and Ancyrodella binodosa (Mouravieff, in Lobato, 1977; Henn, 1985). And, in the upper part of the same limestones an important multilobate pharciceratid radiation (Pharciceras pargai, $P$. applanatum, $P$. cf. pargai, $P$. sp. A, Timanites ? taouzense, and Stenopharciceras cf. kseirense (Henn, 1985; Montesinos \& Henn, 1986) occurs. This radiation would represent the post-Taghanic Event phase in the region (GarcíaAlcalde et al., 1988) that occurs in the Hermanni Zone

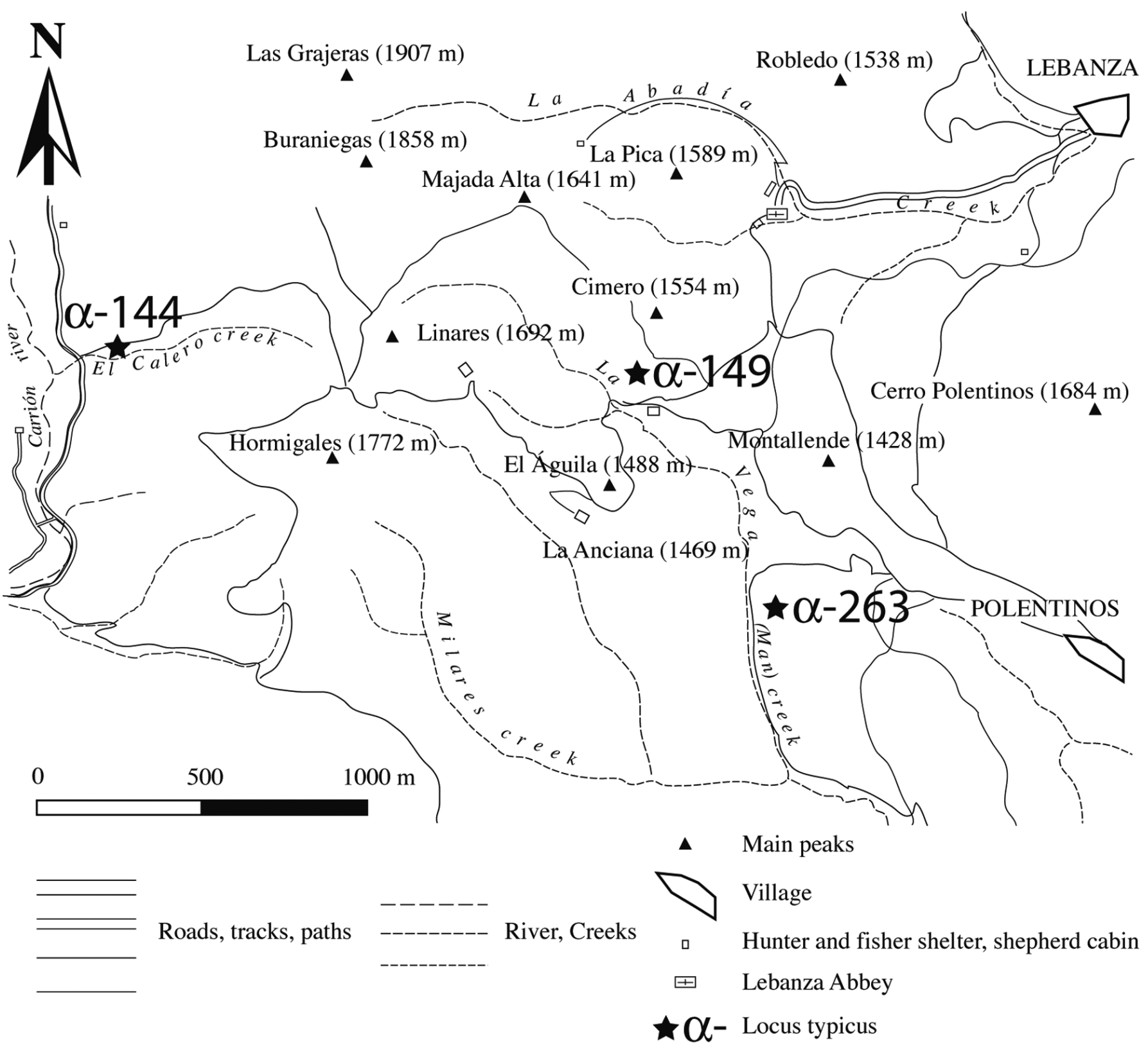

Figure 4. Geographical setting of the type localities of the new species proposed herein: Prodavidsonia havliceki n. sp. ( $\alpha-263)$, "Pyramidalia" palentina n. sp. ( $\alpha-144)$, and Cingulodermis sotoana n. sp. $(\alpha-149)$. 
(compare with MD III B to C Faunas in Becker \& House, 1994). In younger levels (note that in the stratigraphical columns by Henn, 1985, Fig. 41, and by Montesinos \& Henn, 1986, Fig. 4, the calcareous lower member of the Cardaño Fm. would be tectonically reversed), Petteroceras errans occurs (probably belonging in the uppermost Givetian Skeletognathus norrisi conodont Zone; compare with Becker \& House, 1994), and Frasnian forms, as Mesobeloceras housei, Mesobeloceras sp. and other Beloceratidae (Henn, 1985; Montesinos \& Henn, 1986) have been found a little higher. The brachiopods recovered at the base of the Cardaño Fm., mainly Ense andrea Struve, 1992 (in a level possibly equivalent to the famous "Pumilio" horizons; Lottmann, 1990a, b) and Parastringocephalus cf. dorsalis d'Archiac \& de Verneuil, 1842 (see below), are currently dated as middle Givetian, Rhenanus/Varcus to lowest Ansatus Zones (Bultynck \& Hollard, 1980; Weddige, 1988; Lottmann, 1990a, b; Becker \& House, 1994; Brice \& Loones, 2002).

The middle and upper parts of the Cardaño Fm. yield Frasnian conodonts, ammonoids, and homoctenids (Adrichem-Boogaert, 1967; Mouravieff in Lobato, 1977;

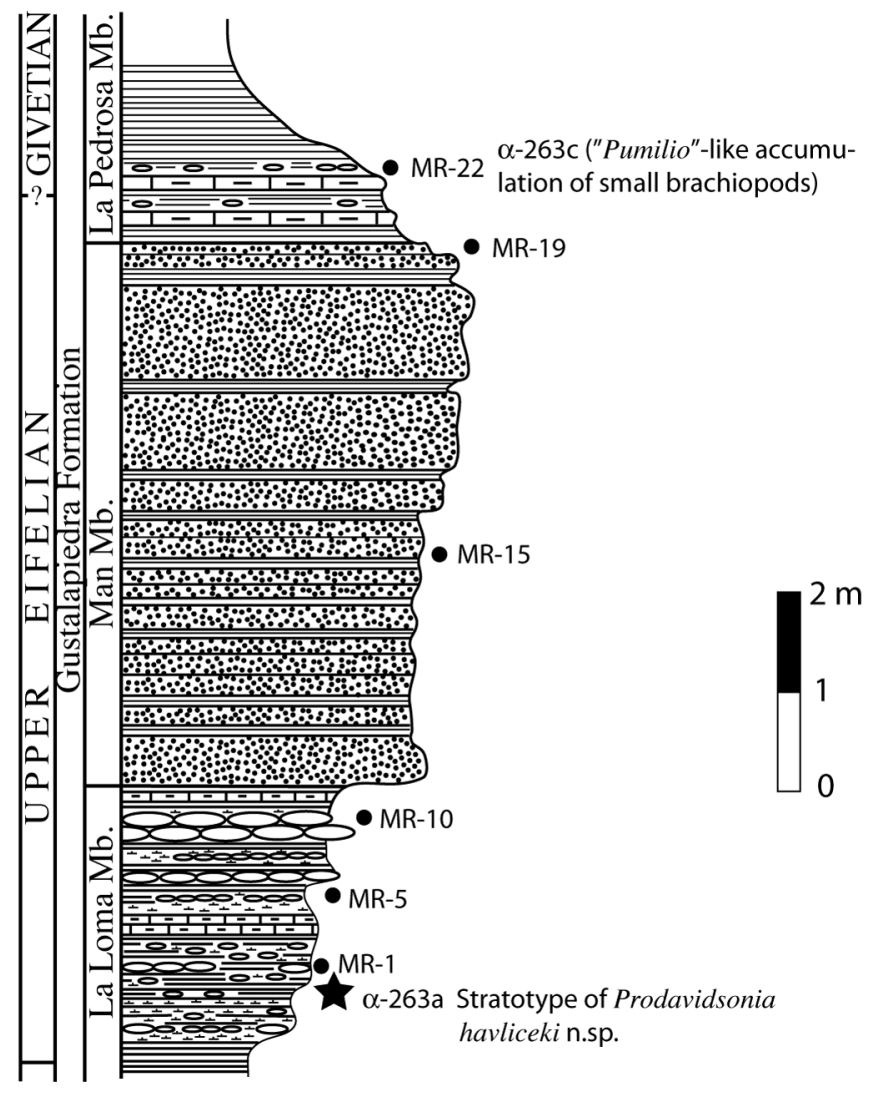

Figure 5. Stratotype (black star) of Prodavidsonia havliceki n. sp. Levels MR-1 and so on: paleontological and magnetosusceptibility sampling. Setting of a layer with a "pumilio"-like accumulation of small, undetermined brachiopods in bed MR-22 (See also García-Alcalde et al., 1990a, Fig. 7). Symbols as in Fig. 3.
Henn, 1985; Montesinos, 1987b; Montesinos \& SánzLópez, 1997; Sánz-López et al., 1999; Truyols-Massoni, 1989, 1999). Finally, the Frasnian/Famennian transition is well represented in the upper part of the Cardaño Fm. (Fig. 3 ), at least in the Gildar-Montó area (Fig. 1), according to the occurrence of conodonts of the Palmatolepis rhenana to Upper P. triangularis Zones (Montesinos \& SánzLópez, 1997, 1999; Sánz-López et al., 1999).

Brachiopods are diverse and abundant in the Devonian nearshore Palentian facies, i.e. in the upper part of the Carazo Fm. (Lochkovian), in the Lebanza Fm. (Lochkovian to Pragian) and in the Lezna Mb. of the Abadía Fm. (upper Emsian) (Binnekamp, 1965; Jahnke et al., 1983; García-Alcalde et al., 1988, 1990b), but their importance fades away in offshore facies. Benthic faunal decrease is specially enhanced from upper Eifelian levels upwards. In fact, no Givetian brachiopod species has been described, figured nor mentioned in the Palentian Domain until now. In this paper, nine species (three new), coming from the Gustalapiedra and Cardaño Fms (Fig. 3) are described and figured. Parastringocephalus cf. dorsalis is the sole stringocephalid found until now in the Palentian Domain, but it is unfortunately represented by a unique specimen, from a not too precisely settled level (it was picked up by students long ago) in the basal calcareous part of the Cardaño Fm. Ense andrea also occurs at the base of the Cardaño Fm. in a thin coquina (maximum thickness: $7 \mathrm{~cm}$ ) composed of thousands, usually disarticulated specimens, in at least one Palentian locality ( $\alpha-36)$ (Fig. 2). In a similar stratigraphical position, in another locality $(\alpha-152)$ (Fig 2$)$ a "pumilio"-like coquina of small, mainly unornamented, yet unclassified brachiopods occurs. The greater part of the studied species occur in outcrops belonging in an antiformal stack, extensively exhumed by the La Vega Creek (likewise called in the region Man River, Los Caños River, Monderrío Creek, and La Riba Creek) and its tributaries (Figs 2, 4). A section, west of the mapped area (Fig. 2), near the confluence of the Carrión River and its tributary, the Calero Creek (Fig. 4), has also yielded several lower to middle Givetian brachiopods but age control by conodont or ammonoid faunas is badly needed therein.

The probable age, and the massive occurrence of Ense andrea in Palencia reminds one of the same species and other Ense forms (E. pumilio, E. albertii), formerly collectively known as "Terebratula pumilio", in levels representing the so-called "Pumilio" Event in Germany, France, Morocco, and Algeria (Lottmann, 1990a, b). In fact the "Pumilio" Event comprises two separate events in those regions, named the Lower and the Upper "Pumilio" Events, the latter subdivided in several lithological units (Lottmann, 1990a, b; papers in El Hassani (ed.), 2004; Bultynck \& Gouwy, 2008; among others). According to Lottmann (1990a, b) the Lower "Pumilio" horizon is a single accumulation of small "pumilio" brachiopod shells that cannot be further subdivided. In this respect the Pal- 
entian horizons could just represent the Lower "Pumilio" event. As indicated above, the "Pumilio" horizons have been dated usually as middle Givetian, Rhenanus/Varcus to Ansatus conodont Zones. However, Ebbighausen et al. (2004) and Becker et al. (2004) reported accumulations of pumiliform brachiopods in a few Eifelian localities in Morocco, and Wendt et al. (2009) suggest an early to middle Givetian age (Timorensis/Rhenanus conodont Zones) for the single "Pumilio" horizon they found in Algeria. A similar accumulation of very minute, non-pumiliform, yet undetermined brachiopods, probably of uppermost Eifelian-lowermost Givetian age, occurs also in the upper part of the Gustalapiedra Fm. locality $\alpha-263 c$ (Figs 2, 5). What triggered these brachiopod events, and whether the great accumulation of shells represents either true "mass mortalities" with transport and allochthonous deposition due to tsunamis, as suggested by Lottmann (1990a, b), or periodic "opportunistic blooms" related to sudden and episodic short-term increase of the trophic level (eutrophication) (Ebbighausen et al., 2004) is debatable (García-Alcalde, 2000). Still, as it has been stated before, accumulation horizons (with different brachiopod forms involved, not only of "pumilio" type) seem more abundant than previously reported (see also Brice \& Ouali Mehadji, 2009).

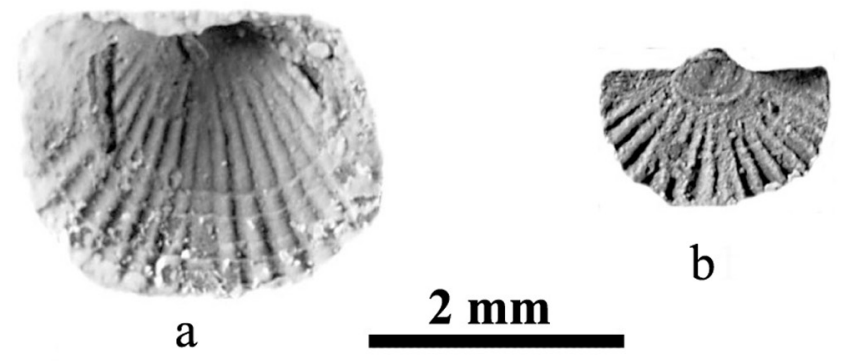

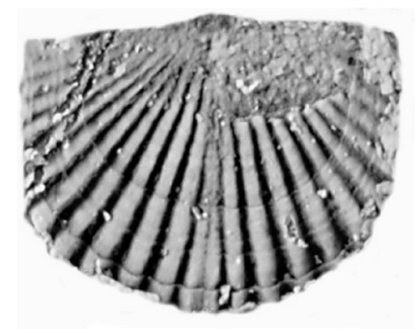

$\mathrm{c} 1$

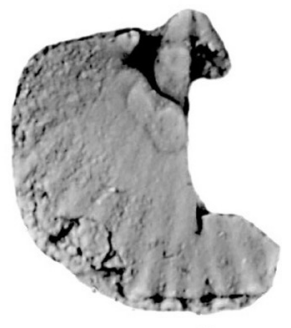

c2
Figure 6. Skenidium cf. polonicum Gürich, 1896. a: external ventral mould, DPO 127850; b: external dorsal mould, DPO 127851, showing the protegular umbonal area, devoid of radial ornamentation; c1-c2: external dorsal mould, and partially broken internal dorsal mould of the same individual, DPO 127849A-B.

\section{SYSTEMATICS}

DPO: acronym of the Área de Paleontología de Oviedo; specimens housed at the collection of the Museo de Geología, Departamento de Geología de la Universidad de Oviedo, Spain. Abbreviations in the tables of measurements: L, length; w, width; $\mathrm{t}$, thickness.

Order PROTORTHIDA Schuchert \& Cooper, 1931

Superfamily Skenidioidea Kozłowski, 1929

Family Skenidiidae Kozłowski, 1929

Genus Skenidium Hall, 1860

Type-species: Orthis insignis Hall, 1859.

$$
\begin{aligned}
& \text { Skenidium cf. polonicum Gürich, } 1896 \\
& \text { Figs 3, } 6 .
\end{aligned}
$$

Material: Four numbered specimens, DPO 127849-127852, and several, unnumbered very badly preserved, doubtful moulds and shell fragments. The specimens DPO 127849-127851 are limonitized moulds coming from the Frasnian shales of the Cardaño Fm., in the locality $\alpha-137$ (Fig. 2). DPO 127849 is an external dorsal mould (A) and an incomplete internal dorsal mould (B) of the same individual (Fig. 6c1-c2). DPO 127850 is an external ventral mould (Fig. 6). DPO 127851 is an external dorsal mould of a juvenile specimen with a marked protegulal umbonal area, including the protegulum itself and the brephic, non plicate shell (Fig. 6). Specimen DPO 127852 is a partial dorsal valve (A) and their external mould (B), coming from mudstones of the lower part of the Cardaño Fm., locality $\alpha-144$ (Figs 3, 4), probably of middle Givetian age.

Descriptive remarks: DPO 127849 A is a minute, slightly convex, transverse dorsal valve (less than $3 \mathrm{~mm}$ length), with the greatest width along the posterior margin that is prolonged in small, acute ears (the left one well preserved in the specimen). Median, narrow and shallow dorsal sulcus. 25-26 high, narrow, subangular, single radial plications with slightly larger, rounded interspaces; on the sulcate median part of the valve there are three weaker radial elements, two of them starting near the umbo of valve, and the third amid the anterior ones, bifurcating from one of them. Growth lines numerous, crowded anteriorly; some of the growth lines, are stronger, irregularly spaced, and imbricate. The internal dorsal mould DPO 127849B, corresponding to the same individual described above, show the broad, bilobed, deep, and rounded septalium typical of skenidiids, extending ahead a quarter of the valve length; septalium supported by a long, thin, acute, very high, tapering off anteriorly, median septum, that reaches $3 / 4$ of the valve length. On the middle part of septalium a strong, ridgelike cardinal process, expanding slightly anteriorly that seems discontinuous with the dorsal median septum, occurs. On both sides of the septalium strong, divergent brachiophores and incomplete fulcral plates occur. The bottom of the septalium is grooved by fine concentric lines indicating the gradual growth of the platform. The external radial ornamentation is weakly reflected in the shell interior on the anterior part of the valve, around the indistinct, unimpressed adductor muscle field (Fig. 6c2).

Specimen DPO 127851 is an external dorsal mould of semicircular outline corresponding to a juvenile individual, ca. 1.5 
mm length, with up to 19 single, straight, strong, radial plications, with a median dichotomous rib, shorter and weaker than the others. A broad, semi-circular, nonplicate, brephic protegular area, furrowed by several concentric growth lines occurs at the umbonal portion of valve, extending ahead $1 / 3$ of the valve length (Fig. 6b).

Specimen DPO 127850 is a damaged external ventral mould of semicircular outline, ca. $2.2 \mathrm{~mm}$ length, strongly convex, transverse, with obtuse hinge angles, provided by more than 21 strong, single, straight, radial plications and a weaker and shorter median dichotomous rib (Fig. 6).

Discussion: The outline, external ornamentation and internal dorsal features of the available specimens are typical of skenidiids, and particularly of the genus Skenidium Hall, 1860. The Palentian forms are closely similar to $S$. polonicum Gürich, 1896, from the Givetian Skały beds in Poland. The very detailed revision of the Polish species by Biernat (1959) has showed, in particular, that the long

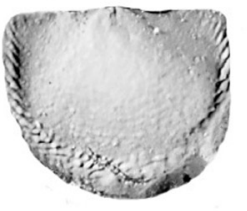

a1

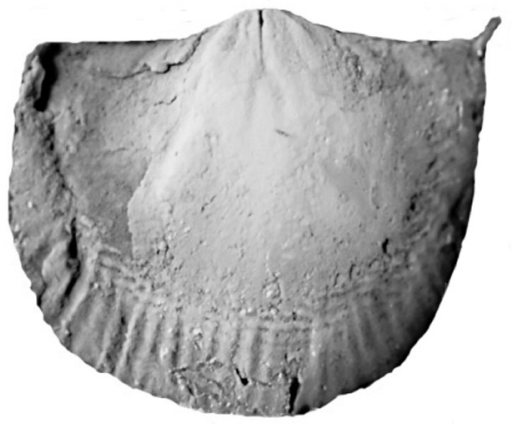

d

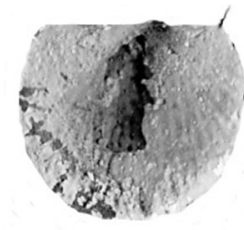

a2

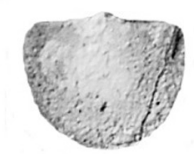

b

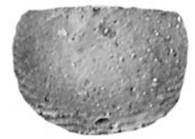

C
Figure 7. Rhyssochonetes cf. douvillei (Rigaux, 1892). a1-a2: internal and external ventral moulds of the same individual, DPO 127890A-A', the former showing the typical corrugated ornamentation, and the latter, an orthomorph, oblique, high-angled cardinal spine; b: internal ventral mould, DPO 127891, showing the corrugated ornamentation; c: internal ventral mould, DPO 127897, showing the corrugated ornamentation; d: internal ventral mould of a great-sized specimen, DPO 127902, showing both the radial and corrugated ornamentation, and an orthomorph, oblique, high-angled cardinal spine. persistence of a marked protegulal area is typical of the species, and it is a feature that occurs also in the Spanish material. The scarce Palentian fossils compel us to leave our form in open nomenclature.

Drot (1961) described from the Givetian of Foum Medza, Dra region (Morocco) an infrequent brachiopod association composed by Skenidium aff. polonicum, Prodavidsonia ? sp., and Parastringocephalus sp. (Stringocephalus sp. 1, in Drot, op. cit., p. 60). Close or identical forms occur in Palencia in Givetian levels of the lower part of the Cardaño Formation, although they have not yet been found associated.

Order PRODUCTIDA Sarytcheva \& Sokolskaya, 1959 Suborder CHONETIDINA Muir-Wood, 1955 Superfamily Chonetoidea Bronn, 1862 Family Chonetidae Bronn, 1862 Subfamily Dagnachonetinae Racheboeuf, 1981 Genus Rhyssochonetes Johnson, 1970

Type-species: Rhyssochonetes aurora solox Johnson, 1970.

\section{Rhyssochonetes aff. douvillei (Rigaux, 1892)} Figs 3, 7; Table 1

Material and localities: 21 specimens, DPO 127882-127885, 127887, 127889-127904, preserved as ventral, internal and external moulds (Figs 2, 4):

-127882 , from locality $\alpha-157$, upper part of the Gustalapiedra Fm., lower Givetian.

-127883, from locality $\alpha-146$, Gustalapiedra Fm., La Loma Mb., upper Eifelian.

-127884, from locality $\alpha-24$, Gustalapiedra Fm., La Loma Mb., upper Eifelian.

-127885, from locality $\alpha-149$, Gustalapiedra Fm., La Pedrosa $\mathrm{Mb}$., lower or middle Givetian.

$-127887,127889$, from locality $\alpha-25$, Gustalapiedra Fm., La Loma Mb., upper Eifelian.

$-127890-127891$, and 127903-127904, from locality $\alpha-166$, Gustalapiedra Fm., La Pedrosa Mb., middle Givetian.

-127892 to 127902 , from locality $\alpha-137$, Cardaño Fm., lower Frasnian.

Descriptive remarks: Small, concavo-convex, weakly transversely elongate (average w/L: 1.29), semicircular shells. Greatest width at the hinge or near it. Ornamentation consists of 26-42 (average: 34 ) rounded, bifurcating and inserted costellae. Orthomorph, oblique, high-angled spines (usually only one spine is visible on the available material; Fig. 7a2, d). Periphery of ventral interior ornamented with numerous, undulating ridges, concentrically disposed and parallel to the anterior commissure but oblique to both the lateral commissures and the postero-lateral ventral margins (Fig. 7a1, b-d). Muscle field subdued, reaching less than $1 / 3$ of length; adductor scars, narrow, longitudinally elliptical, separated by a short, narrow, sharp myophragm; diductor scars subtriangular, longitudinally ridged, with rounded anterior margins, prolonged forward the adductor scars; two inconspicuous, divergent vascular trunks start at the adductor anterior margins, bordering the internal margins of diductor (Fig.7a1, d). Dorsal interior unknown. 
Table 1. Measurements of Rhyssochonetes aff. douvillei.

\begin{tabular}{|l|c|c|c|c|}
\hline \multicolumn{1}{|c|}{ DPO } & $\mathrm{L}$ & $\mathrm{w}$ & $\mathrm{L} / \mathrm{w}$ & $\mathrm{N}^{\mathrm{o}}$ of costellae \\
\hline 127882 & 1.80 & 2.04 & 1.13 & 36 \\
\hline 127883 & 2.07 & 2.73 & 1.32 & - \\
\hline 127884 & 1.53 & 1.73 & 1.13 & 34 \\
\hline 127885 & 1.53 & 2.33 & 1.52 & 30 \\
\hline 127887 & 2.13 & 2.67 & 1.25 & 38 \\
\hline 127890 (Fig.7a1-a2) & 2.47 & 3.07 & 1.24 & 34 \\
\hline 127891 (Fig.7b) & 1.47 & 1.87 & 1.27 & - \\
\hline 127895 & 2.33 & 3.27 & 1.40 & - \\
\hline 127896 & 2.33 & 3.33 & 1.43 & 34 \\
\hline 127897 (Fig.7c) & 1.93 & 2.40 & 1.24 & - \\
\hline 127898 & 3.60 & 4.80 & 1.33 & 36 \\
\hline 127901 & 2.47 & 2.87 & 1.16 & 26 \\
\hline 127902 (Fig.7d) & 5.07 & 6.27 & 1.24 & 42 \\
\hline 127903 & 1.47 & 2.07 & 1.41 & - \\
\hline 127904 & 1.27 & 1.67 & 1.31 & 32 \\
\hline
\end{tabular}

Discussion: The outline, the disposition of ventral spines, the number and morphology of costellae, and the corrugated ventral interior of the described forms reminds one of Rhyssochonetes douvillei (Rigaux, 1892) from the Givetian of the Boulonnais, France. The Spanish shells are, however, smaller, more strongly concavoconvex and their dorsal interior is unknown. Due the poor preservation this material is left for the moment in open nomenclature.

Order ATRYPIDA Rzhonsnitskaia, 1960

Suborder DAVIDSONIIDINA Copper, 1996

Superfamily Davidsonioidea King, 1850

Family Davidsoniidae King, 1850

Genus Prodavidsonia Havlíček, 1956

Type-species: Prodavidsonia dalejensis Havlíček, 1956.

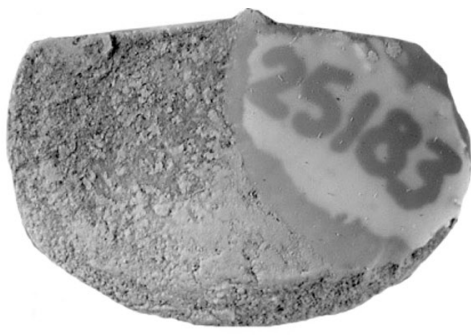

a1

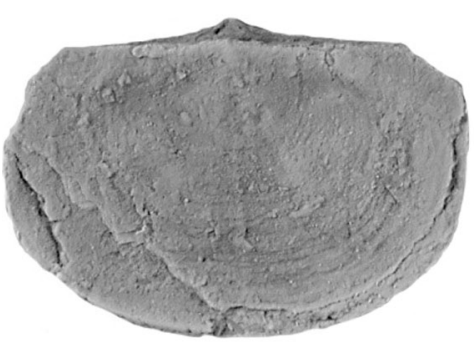

a2

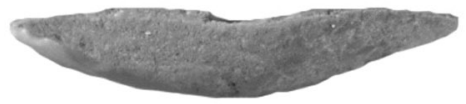

a3

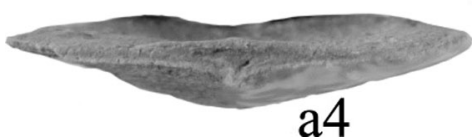

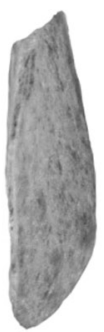

a5

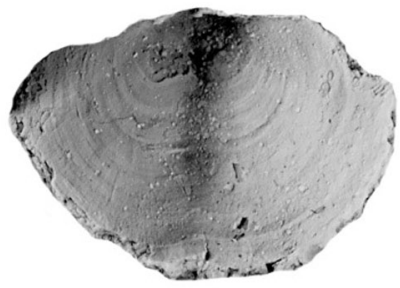

C

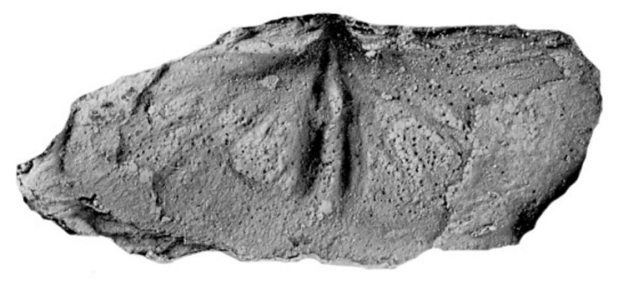

d

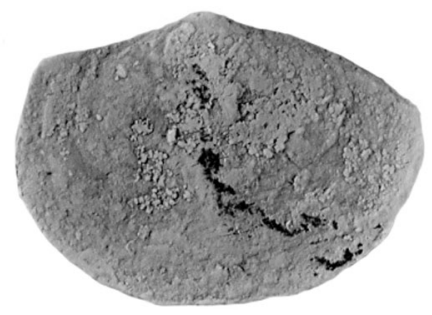

b1

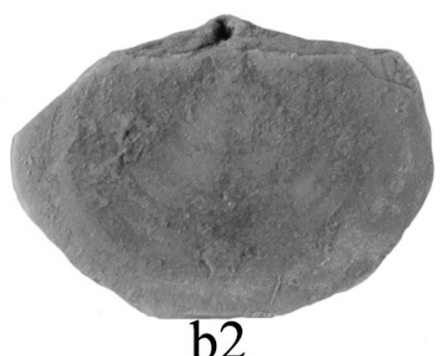

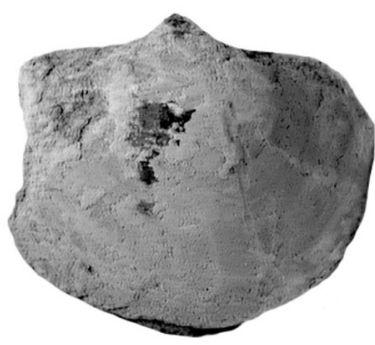

e1

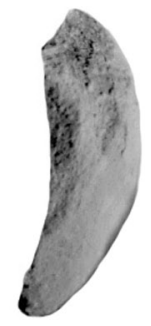

e2
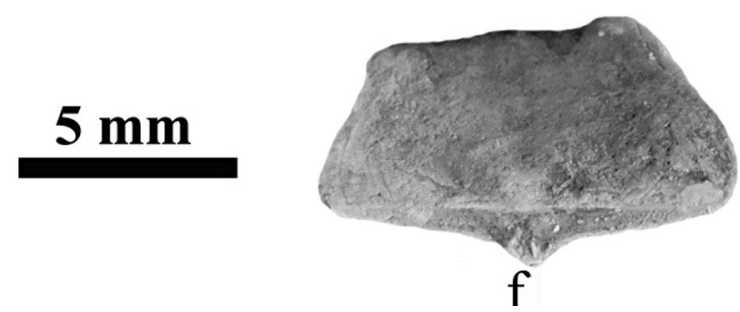

Figure 8. Prodavidsonia havliceki n. sp. a1-a5: Holotype DPO 25183, ventral, dorsal, anterior, posterior, and lateral views. b1-b2: partially broken specimen DPO 34098, ventral and dorsal views; c: external ventral mould, DPO 127846, showing the medial carina and the concentric ornamentation; d: Paratype DPO 25184, latex of an internal ventral mould; e1-e2: partially broken specimen DPO 127848, ventral and lateral views; f: specimen DPO 13271, postero-dorsal view showing the ventral interarea, deltidium, and foramen. 
Prodavidsonia havliceki n. sp. Figs 3, 5, 8; Table 2

v. 1990a Prodavidsonia dalejensis Havlíček; García-Alcalde in García-Alcalde et al., Fig. 7, Fig. 9.18-19.

v. 1990a Quasidavidsonia cf. vicina (Havlíček); García-Alcalde in García-Alcalde et al., Fig. 7, Fig. 9.20.

v. 1990b Prodavidsonia sp.; García-Alcalde in García-Alcalde et al., Fig. 1.

v. 1999 Prodavidsonia cf. dalejensis; García-Alcalde, Fig. 2.

v. 1999 Quasidavidsonia cf. vicina; García-Alcalde, Fig. 2

v. 2009 Prodavidsonia dalejensis Havliček, 1956; GarcíaAlcalde, p. 81, Fig. 2, Fig 5a-c.

v. 2009 Quasidavidsonia cf. vicina; García-Alcalde, Fig. 5c.

Derivatio nominis: In honour of the late Prof. Vladimir Havlíček, Ustřední ústav geologicky, Prague, Czech Republic, for his vast contribution to the study of Palaeozoic brachiopods.

Material: Holotype DPO 25183 (figured in García-Alcalde, 2009, Fig. 5.a1-a2, and herein, Fig. 8a1-a5) and Paratype DPO 25184 (figured in García-Alcalde, 2009, Fig. 5.c, and herein, Fig. 8d) from the locus and stratum typicum. Four specimens, DPO 13271, 34098, 127847-127848, near the El Calero Creek and the Carrión River confluence, Carrión River Valley, ENE of Vidrieros, Palencia, black shales with sparse mudstone nodules in the uppermost part of the La Pedrosa Mb., Gustalapiedra Formation, middle Givetian, locality $\alpha-144$ (Figs 3, 4). Two specimens, DPO 127845-127846, from the upper part of La Pedrosa Mb., Gustalapiedra Fm., lower or middle Givetian, locality $\alpha-149$ (Figs. 2-4). One specimen DPO 127872, from the lower part of the Cardaño Fm. (middle Givetian), locality $\alpha-145$ (Figs 2, 3).

Locus and stratum typicum: Locality $\alpha$-263a (Figs 2, 4). An usually dry, small tributary of the La Vega (=Man) Creek in the eastern slope of the La Vega Creek valley, ca. $800 \mathrm{~m} \mathrm{WSW}$ of La Pedrosa Saddle, at the altitude of 1,180 m. Dark grey shales and marly, nodular limestones of the upper part of La Loma Mb., Gustalapiedra Fm., ca. $2 \mathrm{~m}$ below the sandstones of the Man Mb., just below level MR-1 (Fig. 5), upper Eifelian.

Diagnosis: Small, transverse shell; weakly developed median ventral carina and dorsal sulcus. Shell ornamented with relatively strong concentric growth lamellae and numerous intervening growth lines. Ventral brachidial cones, low.

Description: Shell liberosessile, symmetrical, small (for the genus) (average of $\mathrm{L}$ and $\mathrm{w}$, for 7 measured specimens; 6.9 and $9.4 \mathrm{~mm}$, respectively; holotype, $\mathrm{L}=7.6 \mathrm{~mm}$; $\mathrm{w}=11.1 \mathrm{~mm}$ ), semicircular to semi-elliptical, wider than long (average w/L: 1.34; Holotype: 1.5), flat (average t/L: 0.26; holotype: 0.26), weakly concavo-convex. Cardinal extremities obtuse, rounded; greatest width near hinge. Anterior commissure rectimarginate. Valves ornamented by numerous, irregularly distributed growth lamellae and intervening growth lines (Fig. 8c). Ventral valve carinate (Fig. 8a1, a4), weakly convex, margins bent in antero-dorsal direction forming a narrow commissural trail (Fig. 8a1, a5, e2); the median carina weakens anteriorly to nearly disappear at the commissure. Ventral beak sharp, slightly projecting, with more or less obtuse apical angle. Interarea low, rather flat, apsacline; deltidium broad, gently convex; pedicle foramen sub-mesothyrid, large, longitudinally elliptical, bounded basally by conjunct deltidial plates (Fig. 8f). Brachial valve weakly concave, provided by an inconspicuous median furrow that widens and weakens anteriorly to nearly disappear at the commissure; dorsal interarea linear or lacking.

Interior of ventral valve (Fig. 8d) with weakly developed, spiral grooves on very low, dorsally directed brachidial cones; strong longitudinal ridge on the bottom of a deep, median furrow, starting at the delthyrial chamber; median ridge provided by a strong button-like swelling, that stands out on the ridge, at the distal end of the adductor scars; diductor scars, weakly flabellate, posterior to the spiral cones; interior surface delicately pitted; vascular markings weakly impressed. Dorsal interior unknown.

Table 2. Measurements of Prodavidsonia havliceki n.sp.

\begin{tabular}{|l|c|c|c|}
\hline \multicolumn{1}{|c|}{ Dimensions (in mm) } & $\mathrm{L}$ & $\mathrm{w}$ & $\mathrm{t}$ \\
\hline $\begin{array}{l}\text { Holotype DPO 25183 (Fig. 5. a1-a2 in } \\
\text { García-Alcalde, 2009; and herein, Fig. } \\
\text { 8a1-a5) }\end{array}$ & 7.6 & 11.1 & 2 \\
\hline DPO 13271 (Fig. 8f) & 7 & ca. 10 & 1.8 \\
\hline $\begin{array}{l}\text { DPO 34098 (fig. in García-Alcalde, 2009, } \\
\text { Fig. 5. b1-b2, and herein Fig. 8.b1-b2) }\end{array}$ & 6.6 & 9.2 & 1.7 \\
\hline DPO 127845 & 6.4 & 7.8 & 1.7 \\
\hline DPO 127846 (Fig. 8c) & 6.4 & 9.3 & - \\
\hline DPO 127848 (Fig. 8e1-e2) & 7.4 & 9.6 & - \\
\hline DPO 127872 & 7 & 9 & - \\
\hline
\end{tabular}

Discussion: The weakly concavo-convex lateral profile and the occurrence of a weak anterior trail in the best-preserved specimens allows us to include the Palentian material in Prodavidsonia Havlíček, 1956 and separate them from all the Quasidavidsonia species, Q. vicina (Havlíček, 1967), Q. mediocarinata (Havlíček, 1967), and Q. tenuissima (Barrande, 1879). Prodavidsonia havliceki n. sp. is smaller, less transverse and more weakly carinate and sulcate than $P$. dalejensis.

Copper (1996, 2002) has considered, with no discussion, Quasidavidsonia Havlíček, 1987 as a junior synonym of Prodavidsonia. The new figures given in the Treatise on Invertebrate Palaeontology (Copper, 2002, Fig. 2a-e) although assigned to Prodavidsonia dalejensis Havlíček, 1956, the type-species of Prodavidsonia, correspond in fact both to the named species (Fig. 2e) and to Quasidavidsonia vicina (Figs 2a-d), the type species of Quasidavidsonia (meaning $Q$. vicina would also be a junior synonym of $P$. dalejensis?). The reversed convexity and convexo-concave profile of the Quasidavidsonia species, easily visible in the referred figures, makes at least debatable both the generic and the supposed specific synonymy (see Havlíček, 1998). 
Order ATHYRIDIDA Boucot, Johnson \& Staton, 1964

Superfamily Dayioidea Waagen, 1883

Superfamily Anoplothecoidea Schuchert, 1894

Family Anoplothecidae Schuchert, 1894

Subfamily Anoplothecinae Schuchert, 1894

Genus Bifida Davidson, 1882

Type-species: Terebratula lepida d'Archiac \& de Verneuil, 1842.

\section{Bifida aff. lepida \\ (d'Archiac \& de Verneuil, 1842)}

Figs. 3, 9; Table 3

v. 1990a Bifida spp.; García-Alcalde in García-Alcalde et al., Fig. 7.

v. 1999 Bifida lepida; García-Alcalde, p. 601, Tabla I.

Material: Ten specimens in variable preservation state, usually as external moulds of isolated valves, DPO 127905-127911

(Figs 2-4):

-DPO 127905 from locality $\alpha$-48a, Gustalapiedra Fm., La Loma Mb., upper Eifelian.

-DPO 127906 from locality $\alpha$-149, Gustalapiedra Fm., La

Pedrosa Mb., lower Givetian.

-DPO 127907-127910 from locality $\alpha-263 a$, Gustalapiedra

Fm., La Loma Mb., upper Eifelian.

-DPO 127911 from locality A.PIN-6, Cardaño Fm., middle

to upper Givetian.

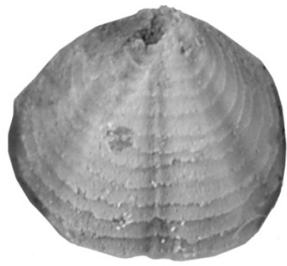

al

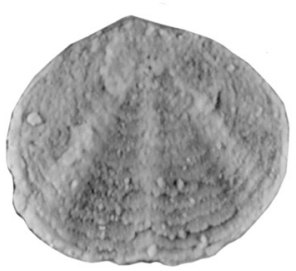

a2

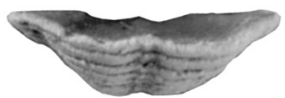

a3

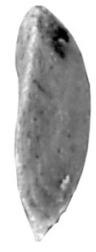

a4

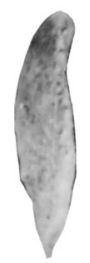

b3
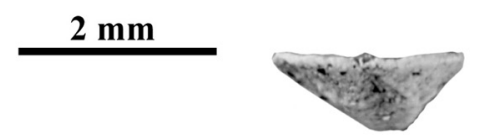

b4
Figure 9. Bifida aff. lepida (d'Archiac \& de Verneuil, 1842). a1a4: ventral, dorsal, anterior, and lateral views of the specimen DPO 127912; b1-b4: ventral, dorsal, lateral, and anterior views of the specimen DPO 127913.
-DPO 127912 from locality B97-44, a complete, articulated shell, Cardaño Fm., middle to upper Givetian.

-DPO 127913-127914 from locality $\alpha$-144, uppermost part of Gustalapiedra Fm., lower to middle Givetian. The DPO 127913 is a complete, articulated shell.

Description: Shell minute (average length: $2.06 \mathrm{~mm}$ ), subcircular to subpentagonal in outline, nearly equidimensional (average w/L: 0.98), strongly unequally biconvex, lenticular (thickness less than $1 \mathrm{~mm}$ ), carinate. Hinge very narrow, greatest width at midlength or slightly anterior. Ventral valve strongly convex, carinate; greatest thickness at midlength or posterior; midpair of strong, rounded plications that start at the apex and widen and lose height gradually anteriorly; one or two pairs of lateral costae, weaker than the median ones. Exceptionally, a fine, narrow, low costa, occurs amidst the midpair (Fig. 9a1, a3). Dorsal valve with a large, median depression and flattened to slightly convex postero-lateral margins; five radial plications: a median, rather strong plication in the middle of the sulcus, and two pairs of bordering lateral costae; the plications start at the apex of valve and widen and lose height gradually anteriorly; the first lateral pair of costae is larger than the median one and stands out of it; the second, postero-lateral pair of costae is very weak, nearly inconspicuous. (Fig. 9a2-a3). Surface of shell provided by numerous, even, imbricate growth lamellae with spiny margins (Fig. 9.a1-a4). Internal characters unknown.

Discussion: Our form reminds us externally of Bifida lepida (d'Archiac \& de Verneuil, 1842). The shell of the latter species is however larger, ventri-biconvex, and longer than wide. Authors have included in B. lepida numerous, possibly different Emsian to Frasnian forms. A revision of the type material is thus badly needed.

The Palentian forms occur in beds of the Gustalapiedra and Cardaño Fms, of upper Eifelian to middle or upper Givetian age.

Table 3. Measurements of Bifida aff. lepida.

\begin{tabular}{|l|c|c|c|c|}
\hline \multicolumn{1}{|c|}{ DPO } & L & w & t & w/L \\
\hline 127905 & 2.13 & 1.87 & - & 0.88 \\
\hline 127906 & 2.20 & 1.87 & - & 0.85 \\
\hline 127907 & 0.93 & 1.13 & - & 1.21 \\
\hline 127908 & 2.33 & 2.47 & - & 1.06 \\
\hline 127909 & 2.27 & 2.27 & - & 1 \\
\hline 127911 & 1.07 & 0.93 & - & 0.87 \\
\hline 127912 (Fig. 9a1-a4) & 2.53 & 2.87 & 1 & 1.13 \\
\hline 127913 (Fig. 9b1-b4) & 2.27 & 2.27 & 0.87 & 1 \\
\hline 127914 & 2.80 & 2.47 & - & 0.88 \\
\hline
\end{tabular}

Order SPIRIFERIDA Waagen, 1883

Suborder SPIRIFERIDINA Waagen, 1883

Superfamily Ambocoelioidea George, 1931

Family Ambocoeliidae George, 1931

Subfamily Rhynchospiriferinae Paulus, 1957

Genus Ambothyris George, 1931

Type-species: Spirifera infima Whidborne, 1893. 


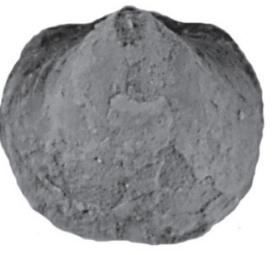

a1

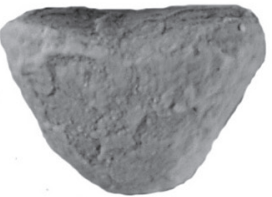

a2

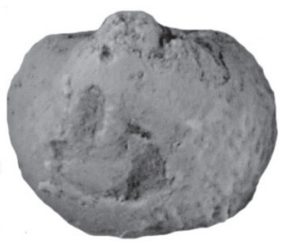

b1

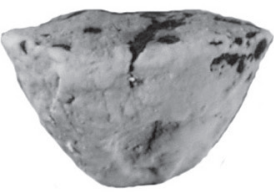

b2

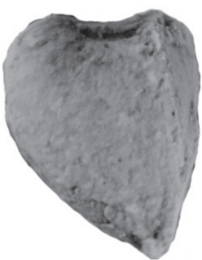

a3
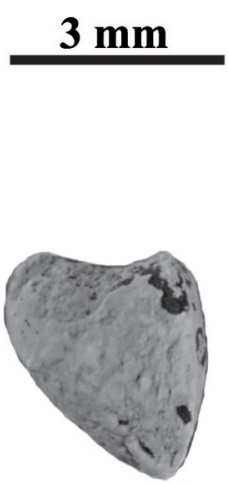

b3

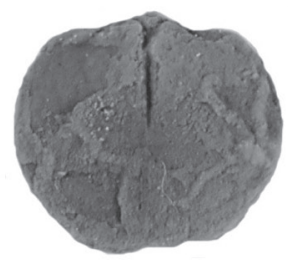

a4

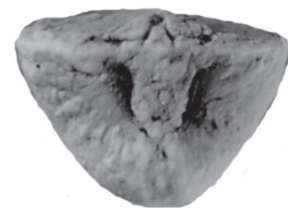

a5

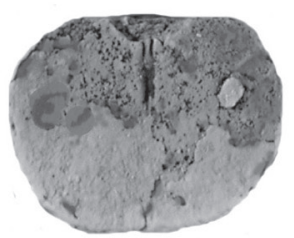

b4

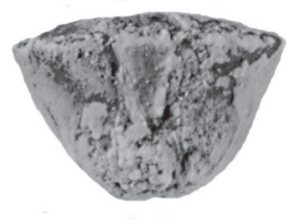

b5
Figure 10. Ambothyris cf. infima (Whidborne, 1893). a1-a5: ventral, anterior, lateral, dorsal, and posterior views of the specimen DPO 127842; b1-b5: ventral, anterior, lateral, dorsal, and posterior views of the specimen DPO 127843.

\section{Ambothyris cf. infima (Whidborne, 1893)}

Figs 3, 10-11; Table 4

Material: Two articulated, strongly weathered specimens, DPO 127842 (locality $\alpha-150$, Fig. 2) and DPO 127843 (locality $\alpha-104$, Fig. 2), upper part of the Gustalapiedra Fm., lower Givetian.

Description: Shell minute, strongly ventri-biconvex, elliptical in outline, slightly wider than long, brachythyrid, with rounded cardinal extremities; surface smooth except for the occurrence of subdued median depressions in both valves; anterior commissure weakly sulcate (Fig. 10a2); antero-lateral margins rounded, turned up dorsally; greatest width at the first third of length; greatest height posterior to midlength. Ventral interarea high, catacline, curved, with ill-defined margins (Fig. 10a3, a5, b3); delthyrium open, broad, occupying more than $1 / 3$ of the interarea width, with discrete, narrow deltidial plates; beak incurved, small; apical angle obtuse. Ventral valve hemipyramidal, umbo inflated, median furrow inconspicuous. Dorsal valve low, weakly and evenly convex; subdued median depression, very enlarged forward. Concentric ornamentation formed by a short number of

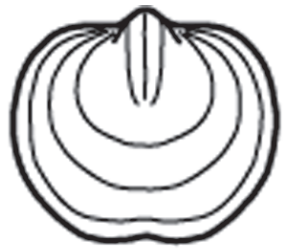

a

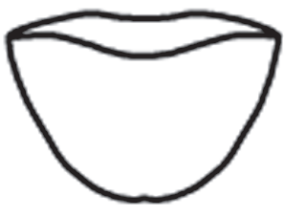

d
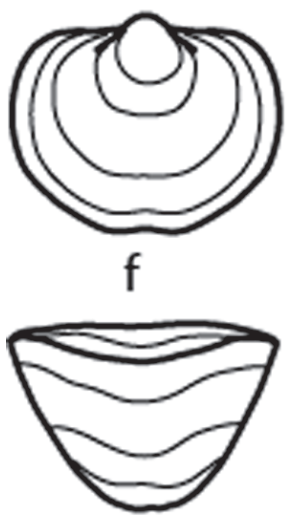

i

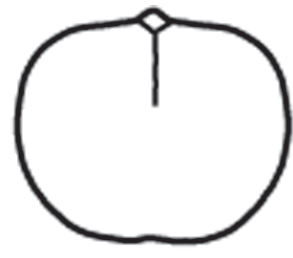

b

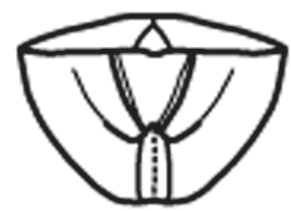

e

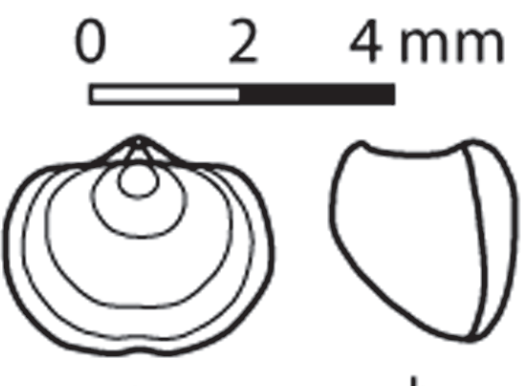

$\mathrm{h}$
Figure 11. Ambothyris cf. infima (Whidborne, 1893). Camera lucida drawing (enlarged and slightly idealized) of the specimens figured in Fig. 10, DPO 127842, a-e: ventral, dorsal, lateral, anterior, and posterior views, partially showing the ventral muscle field and the crural plates uniting anteriorly; and DPO 127843 , f-j: ventral, dorsal, lateral, anterior, and posterior views, showing both the concentric ornamentation and the high, catacline interarea.

Table 4. Measurements of Ambothyris cf. infima.

\begin{tabular}{|c|c|c|c|c|}
\hline DPO & L & w & t & w/L \\
\hline 127842 (Fig. 10a1-a5) & 3.3 & 3.6 & 2.6 & 1.1 \\
\hline 127843 (Fig. 10b1-b5) & 3.4 & 3.7 & 2.5 & 1.1 \\
\hline
\end{tabular}

strong growth lamellae crowded anteriorly and finer intervening lines. Shell substance fibrous, impunctate. The radial fibrous fabric of shell, visible in exfoliated parts of the studied specimens, sometimes gives the impression of a capillate microornament. Dental plates lacking, ventral muscle field, long, narrow, weakly impressed. Crural plates long, converging anteriorly (Fig. 10a4, b4; Fig. 11b); dorsal muscle field inconspicuous. 


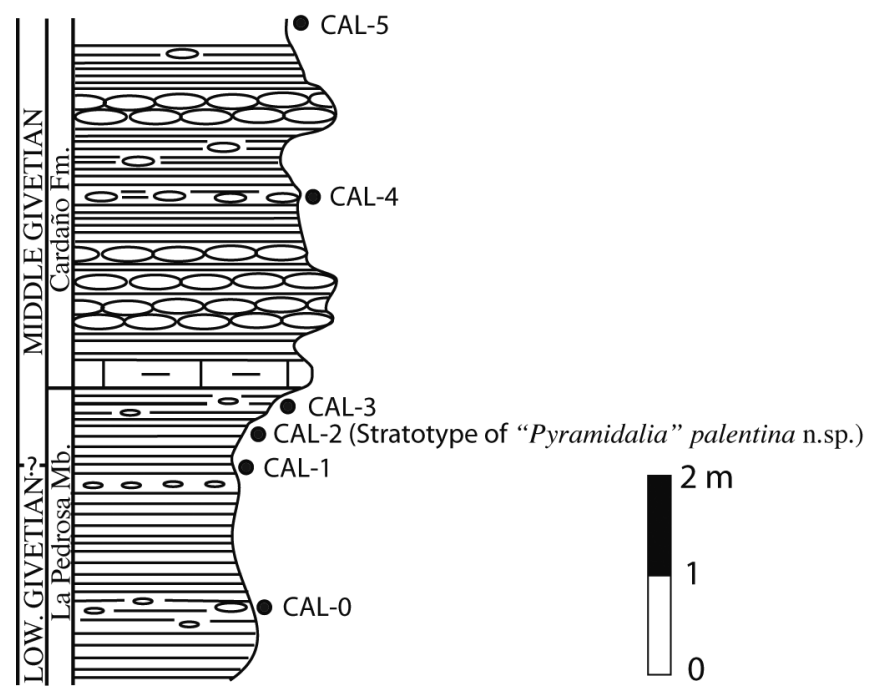

Figure 12. Stratotype of "Pyramidalia" palentina n. sp. Levels CAL-1 and so on: sampling for conodonts. Symbols as in figure 3.

Remarks: The described form reminds us very much Ambothyris infima, but differs slightly in outline and lateral profile.

Suborder DELTHYRIDINA Ivanova, 1972

Superfamily Reticularioidea Waagen, 1883

Family Reticulariidae Waagen, 1883

Genus Pyramidalia Nalivkin, 1947

Type-species: Spirifera simplex Phillips, 1841.

\section{"Pyramidalia" palentina n. sp. \\ Figs. 3, 12-14; Table 5}

v. 1990a Pyramidalia simplex; García-Alcalde, in García-Alcalde et al., Fig. 7

Derivatio nominis: After the name Palencia, the Spanish province where the species has been found.

Material: Holotype DPO 127824 (Fig. 14a1-a5) and four paratypes, DPO 127825-127828 from the locus and stratum typicum. Two specimens, DPO 127829-127830 (the latter sectioned to show the pedicle interior, Fig. 13), from the locality $\alpha-104$, a shepherd path between the La Abadía de Lebanza-Polentinos track and the La Abadía de Lebanza-Carrión valley track, near the El Águila water trough (Fig. 2), upper part of the Gustalapiedra Fm., lower to middle Givetian (Fig. 3). Four specimens, DPO 127820-127823 (Fig. 14a1-a5), from the locality $\alpha-149$, southern Cimero Peak slope, above the La Abadía de Lebanza-Carrión valley track, NW of a shepherd's hut, at the altitude of 1,400 m (Figs 2, 4), upper part of the Gustalapiedra Fm., lower to middle Givetian (Fig. 3).

Locus and stratum typicum: Section near the El Calero Creek and the Carrión River confluence, Carrión River valley, ENE of Vidrieros, Palencia (Fig. 4). Black shales with sparse mudstone nodules of the uppermost part of the La Pedrosa Mb., Gustalapiedra Formation, $\alpha-144$, level CAL-2 (Figs. 3, 12). Possibly middle Givetian.

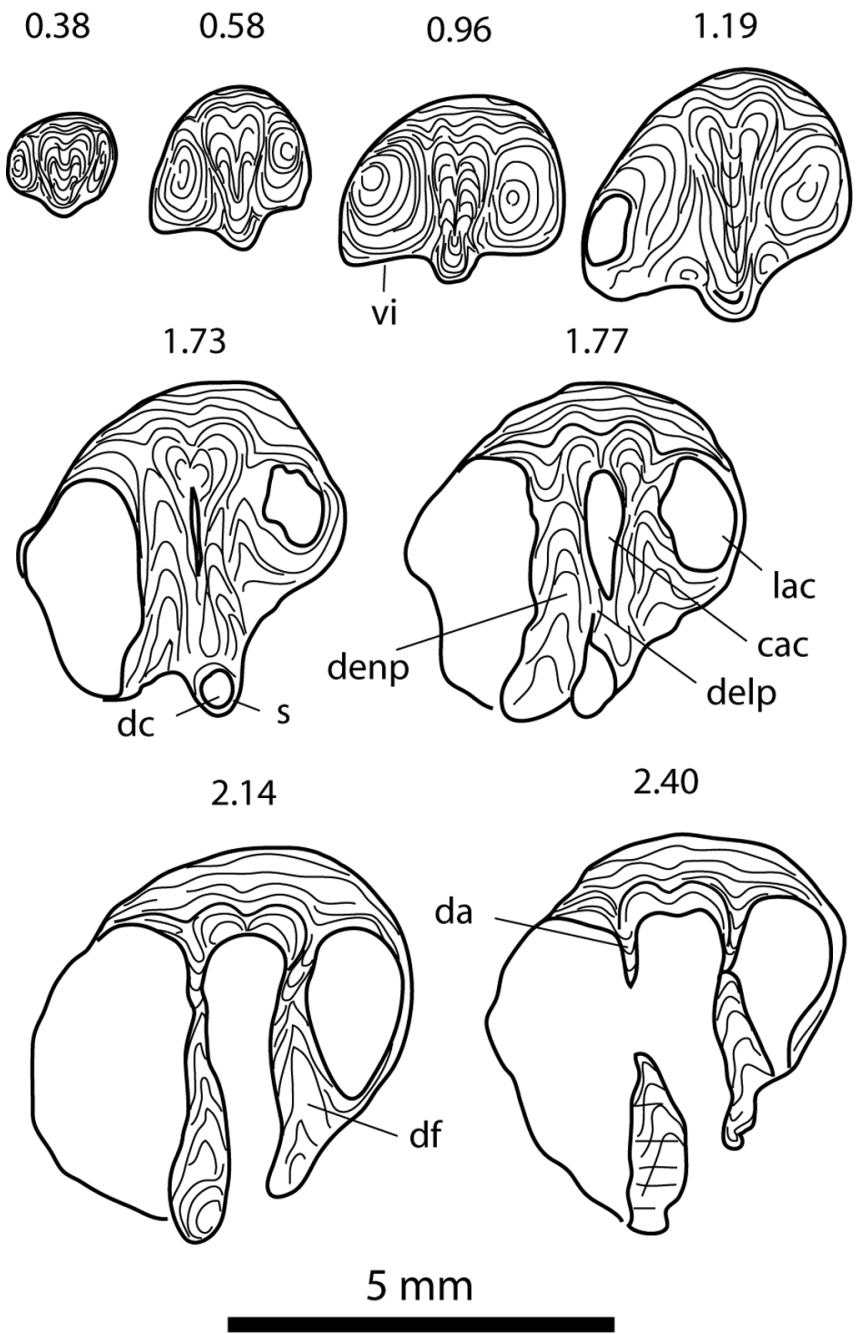

Figure 13. "Pyramidalia" palentina n. sp. Camera lucida drawing of the serial sections of the specimen DPO 127830. Distances in mm measured to the ventral apex. cac: Central apical cavity; da: dental adminiculum; dc: delthyrial cavity; df: dental flange; delp: delthyrial plate; denp: dental plate; lc: lateral apical cavity; s: symphytium; vi: ventral interarea.

Diagnosis: Shell impunctate, small, smooth, strongly ventri-biconvex, transversely ellipsoidal, brachythyrid, with very rounded cardinal extremities. Ventral sinus and dorsal fold obscure, narrow. Ventral valve hemipyramidal; interarea high, strongly apsacline to catacline, even procline, longitudinally curved; delthyrium narrow, covered by a nearly complete, strong symphytium with a minute, non-functional apical foramen and a relatively large basal arc. Dental plates short, thin, weakly divergent, with well-differentiated dental flanges and adminicula. Apical plates joining below level of interarea forming a delthyrial plate situated high into the delthyrial cavity. Cardinal process bilobed, apparently non-striated, crural plates short, sub-parallel. 
Description: Shell smooth, small (Lmax $8.2 \mathrm{~mm}$ ), ventri-biconvex, strongly inflated (average: $t$ up to $80 \%$ of $\mathrm{L}$ for 4 measured specimens; $\mathrm{t} / \mathrm{L}$ of the holotype: 0.84 ), transversely ellipsoidal (average L 79\% of w for 4 measured specimens; w/L of the holotype: 1.25 ), with very rounded cardinal extremities and hinge shorter than maximum width (hinge width ca. $70 \%$ of the maximum width); maximum width at midlength; maximum height at the umbonal region. Shell substance impunctate. Test radially grooved internally giving the impression of a microcostulate ornament in exfoliated shells.

Ventral interarea, very high, curved, strongly apsacline to catacline, even slightly procline, transversally striated, twice wider than high, with ill-defined, rounded interarea margins (Fig. $14 \mathrm{a} 4, \mathrm{a} 5, \mathrm{c} 2, \mathrm{c} 5)$; delthyrium rather narrow, ca. 1/4 of the hinge width, covered by a nearly complete, strongly convex symphytium; symphytium with a relatively large basal arc provided by an apical, minute, probably non-functional (because of secondary infilling) foramen (Fig. 14a4, b, c5); umbo large with a short, pointed, erect to incurved beak, apical angle up to $120^{\circ}$ (aver-

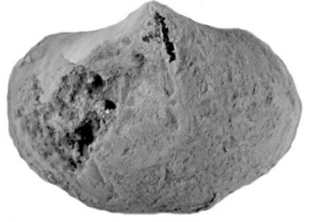

a1

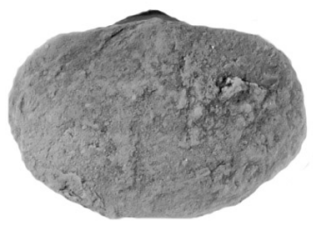

a2

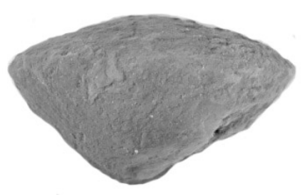

a3

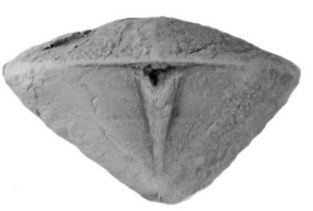

a4

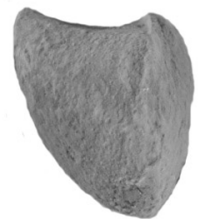

a5

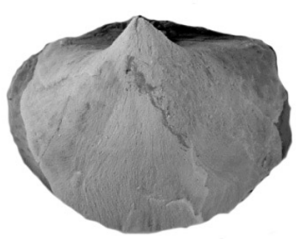

c1

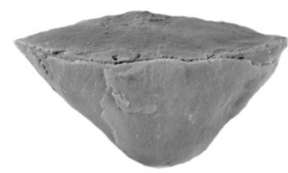

c4

age: $105^{\circ}$, for 7 measured specimens; holotype: $110^{\circ}$ ). Dorsal interarea almost flat, very low, orthocline to anacline; wide, open notothyrium, with narrow, marginal chilidial plates; umbo faint with a small rounded beak.

Ventral sinus and dorsal fold subdued, narrow (width of sinus and fold less than $1 / 3$ of the shell width), rounded, weakly marked anteriorly; anterior commissure faintly uniplicate, rounded (Fig. 14a3, c4); antero-lateral commissures rounded, curving slightly dorsally. Ventral valve strongly convex; greatest thickness at the umbonal region. Dorsal valve weakly and evenly convex; greatest thickness at midlength. Growth lamellae few, usually much eroded. Micro-ornamentation obscure due to shell exfoliation; some preserved parts of the test show files of concentrically disposed, minute granules. Shell substance impunctate.

Dental plates thin, rather short, weakly divergent with well differentiated massive dental flanges and thin adminicula; conjunct apical plates joining to form a massive delthyrial plate situated high into the delthyrial cavity, plunged posteriorly into secondary shell (Fig. 13); a longitudinal, low, wide, median

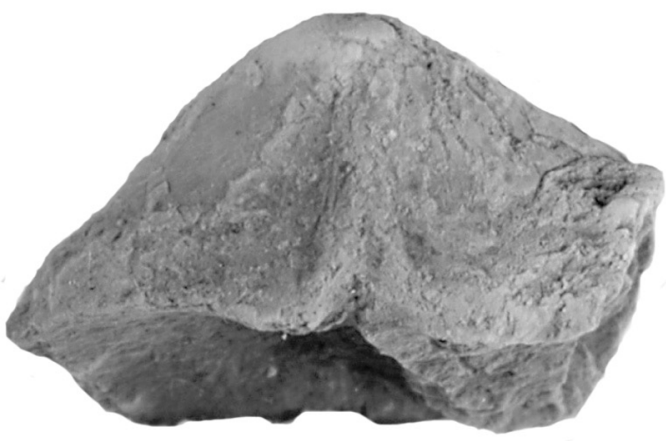

b

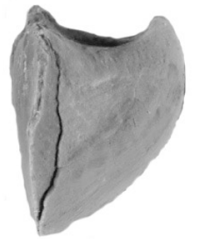

c2

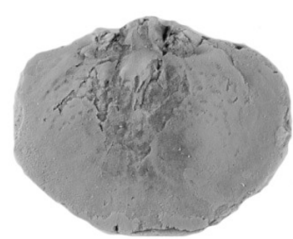

c3

Figure 14. "Pyramidalia" palentina n. sp. a1-a5: Holotype DPO 127824, ventral, dorsal, anterior, posterior, and lateral views; b: posterior oblique view of a partially broken ventral valve DPO 127823 showing the secondarily infilled apical foramen; c1-c5: ventral, lateral, dorsal, anterior, and posterior views of a slightly crushed specimen DPO 127829. Scale bars: 5 mm. 
Table 5. Measurements of "Pyramidalia" palentina n.sp.

\begin{tabular}{|l|c|c|c|c|c|c|}
\hline \multicolumn{1}{|c|}{ DPO } & $\mathrm{L}$ & $\mathrm{w}$ & $\mathrm{t}$ & $\mathrm{w} / \mathrm{L}$ & $\mathrm{t} / \mathrm{L}$ & Apical angle \\
\hline Holotype 127824 (Fig. 14a1-a5) & 8 & 10 & 6.7 & 1.25 & 0.84 & $110^{\circ}$ \\
\hline Paratype 127827 & - & 6.7 & - & - & - & $115^{\circ}$ \\
\hline Paratype 127828 & - & - & 9.5 & - & - & $110^{\circ}$ \\
\hline 127820 & 4.5 & 6.3 & 3.4 & 1.40 & 0.75 & $-119^{\circ}$ \\
\hline 127821 & 8 & 8.9 & - & 1.11 & - & $97^{\circ}$ \\
\hline 127823 & 5.1 & 7 & 4.5 & 1.47 & 0.88 & - \\
\hline 127829 (Fig. 14c1-c5) & 8.2 & 9.9 & 5.6 & 1.20 & 0.68 & \\
\hline
\end{tabular}

ridge starts at the apex but it is also plunging into secondary shell along the delthyrial chamber (Fig. 13). Crural plates very short, sub-parallel, visible both on partial internal moulds and by transparency. Strong, bilobed, smooth cardinal process infilling the nothothyrial opening. Muscle fields not visible usually on available material. On an internal dorsal mould (DPO 127829) a rectangular, longer than wide, quadripartite, with a rather strong relief, transversally ridged dorsal muscle field is barely visible (Fig. 14c3).

Discussion: Our species reminds us of several small, smooth, hemipyramidal forms assigned to Spirifera simplex Phillips, 1841 in different generic combinations (i.e. associated with Reticularia, Eoreticularia, Cyrtia, Plectospirifer, Thomasaria, Cyrtinaella, or Pyramidalia) (see synonymies and discussions in Vandercammen, 1957; Drot, 1964; Balinski, 1979; Oleneva, 2006). Pyramidalia has been considered even as a junior synonym either of Cyrtinaella (i.e. Pitrat, 1965, in Treatise on Invertebrate Paleontology, p. 678), Squamulariina (i.e. Johnson, 2006, in Treatise on Invertebrate Paleontology, p. 1882), or Thomasaria (i.e. Balinski, 1979). But, in fact, neither an endopunctate structure nor a median ventral septum have been observed by authors describing "simplex" forms (i.e. Vandercammen, 1957; Drot, 1964; Balinski, 1979; among others), and the same applies to the species discussed herein. Consequently, it must be rejected that these forms belong in the Superfamily Cyrtinoidea. On the other hand, Thomasaria lacks both the strongly convex symphytium and the small crural plates of Pyramidalia, their cardinal angles are acute or at right angles, not rounded as in $P y$ ramidalia, and the dental plates are longer than in the latter genus. In consequence, Pyramidalia would be a valid taxon, but waiting for the necessary revision of Phillips's types we prefer for the moment to use the name with reservation. The supra-generic affiliation of Pyramidalia is obscure. It must belong to the Family Reticulariidae Waagen, 1883 but no genera of the accepted Subfamilies of the taxon shows the strong pseudodeltidium-like symphytium, typical of Pyramidalia forms.

"Pyramidalia" palentina n. sp. is smaller than " $P$." simplex Phillips, lacks radial plications on the shell flanks, and the ventral sinus and dorsal fold are weaker. It also differs from Thomasaria cf. altumbona Mottequin, 2008 non Stainbrook, 1945, from the Frasnian of the Neuville Formation, Namur-Dinant Basin (Belgium), in the greater development of the ventral interarea and symphytium, weaker ventral sinus, dorsal fold and ventral tongue, and occurrence of crural plates.

Suborder SPIRIFERIDINA Waagen, 1883

Superfamily Martinioidea Waagen, 1883

Family Tenellodermidae Carter, Johnson \& Gourvennec (in Carter et al., 1994)

\section{Genus Cingulodermis Havlíček, 1971}

Type-species: Cingulodermis cinctus Havlíček, 1971.

Remarks: The genus Cingulodermis was introduced by Havlíček (1971) for brachythyrid, smooth, weakly differentiated shells, devoid of radial capillae, surficial pits or minute spines, but with strong concentric lamellae, short dental plates, non-striate cardinal process, and crural plates separated, touching the bottom of valve in proximity to the hinge. Micro-ornament features allowed the author of the genus to separate it from Eomartiniopsis where most of Cingulodermis species were initially assigned. Cingulodermis resembles Eoreticularia Nalivkin in Frederiks, 1924 in external outline and smooth shell surface. The latter genus, however differs from Cingulodermis in the granulate micro-ornamentation and in the crural plates not resting on the valve floor, sometimes united to a short median dorsal ridge.

\section{Cingulodermis sotoana n. sp.}

Figs 3, 15-17; Table 6

v. 1999 Eoreticularia fraterna (Barrande, 1879); GarcíaAlcalde, Fig. 7

Derivatio nominis: Named after Francisco M. Soto Fernández, colleague in the Palaeontology section of the Faculty of Geology of Oviedo, but above all my close friend.

Material: Thirteen specimens, comprising either complete shells or external and internal moulds in variable preservation state. 


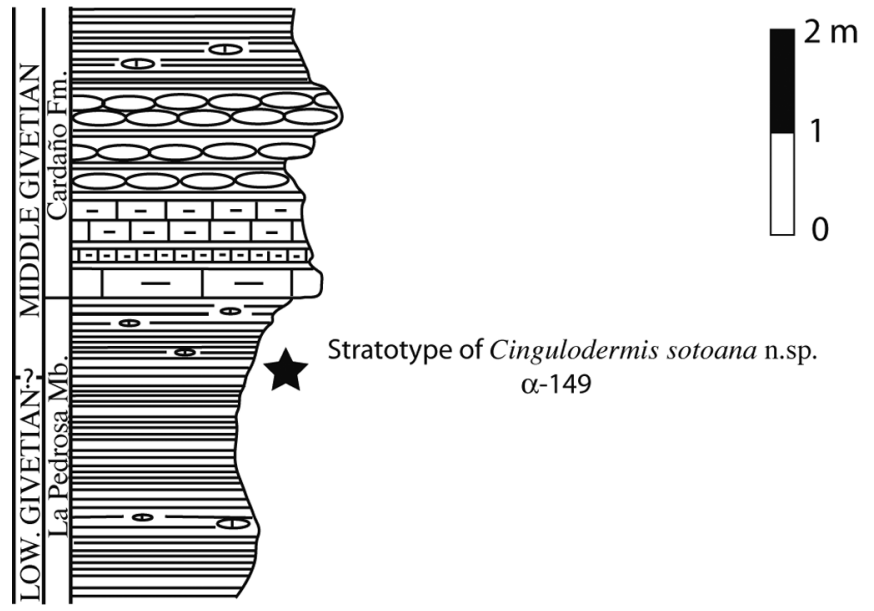

Figure 15. Stratotype of Cingulodermis sotoana n. sp. (black star). Symbols as in figure 3.

Holotype DPO 127834 (Fig. 17a1-a5) and Paratype DPO 127833 (Fig. 17f1-f4), both from the locus and stratum typicum. The other specimens come from the localities and stratigraphical settings below (Figs 2-4):

Gustalapiedra Fm., La Loma Mb., upper Eifelian:

Locality $\alpha$-264; DPO 34112, 127840.

Locality $\alpha$-263c: DPO 127835-127837.

Locality $\alpha-178:$ DPO 127838.

Locality $\alpha-150$ : DPO 127831-127832.

Gustalapiedra Fm., La Pedrosa Mb, uppermost Eifelian to middle Givetian:

Locality $\alpha$-144; DPO 127841.

Locus and stratum typicum: Southern slope of the Cimero Peak, near the track La Abadía de Lebanza-Carrión Valley, NW of a shepherd's hut, at the altitude of 1,400 m, locality $\alpha-149$ (Figs. 2, 4). Black shales of the uppermost part of the Gustalapiedra Fm., top of La Pedrosa Member (Fig. 15), lower to middle Givetian.

Diagnosis: Shell of small size for the genus, moderately transverse, strongly ventri-biconvex, with rounded cardinal extremities and incurved beaks overhanging the cardinal area. Fold and sulcus well defined anteriorly resulting in uniplicate commissure. Ventral interarea, high, relatively flattened, apsacline to catacline, bounded laterally by very weak edges; delthyrium open. Surface of valves non costate. Growth lamellae few, strong, irregularly spaced with fine, numerous, intervening growth lines. Micro-ornamentation devoid of radial capillae, surficial pits or spines. Dental plates, strong, of more or less curved bases, moderately divergent; ventral muscle field well impressed into the shell, partially extending beyond the distal ends of dental plates. Dorsal muscle field slightly impressed. Cardinal process small, non-striate; crural plates short, sub-parallel.

Description: Shell small (Lmax: $10 \mathrm{~mm}$ ), ventri-biconvex, inflated (average: $t$ up to $74 \%$ of $L$ for 7 measured specimens; $t / 1$ of the holotype: 0.76), sub-pentagonal outline, wider than long (average: L $82 \%$ of $w$ for 8 measured specimens; w/L of the
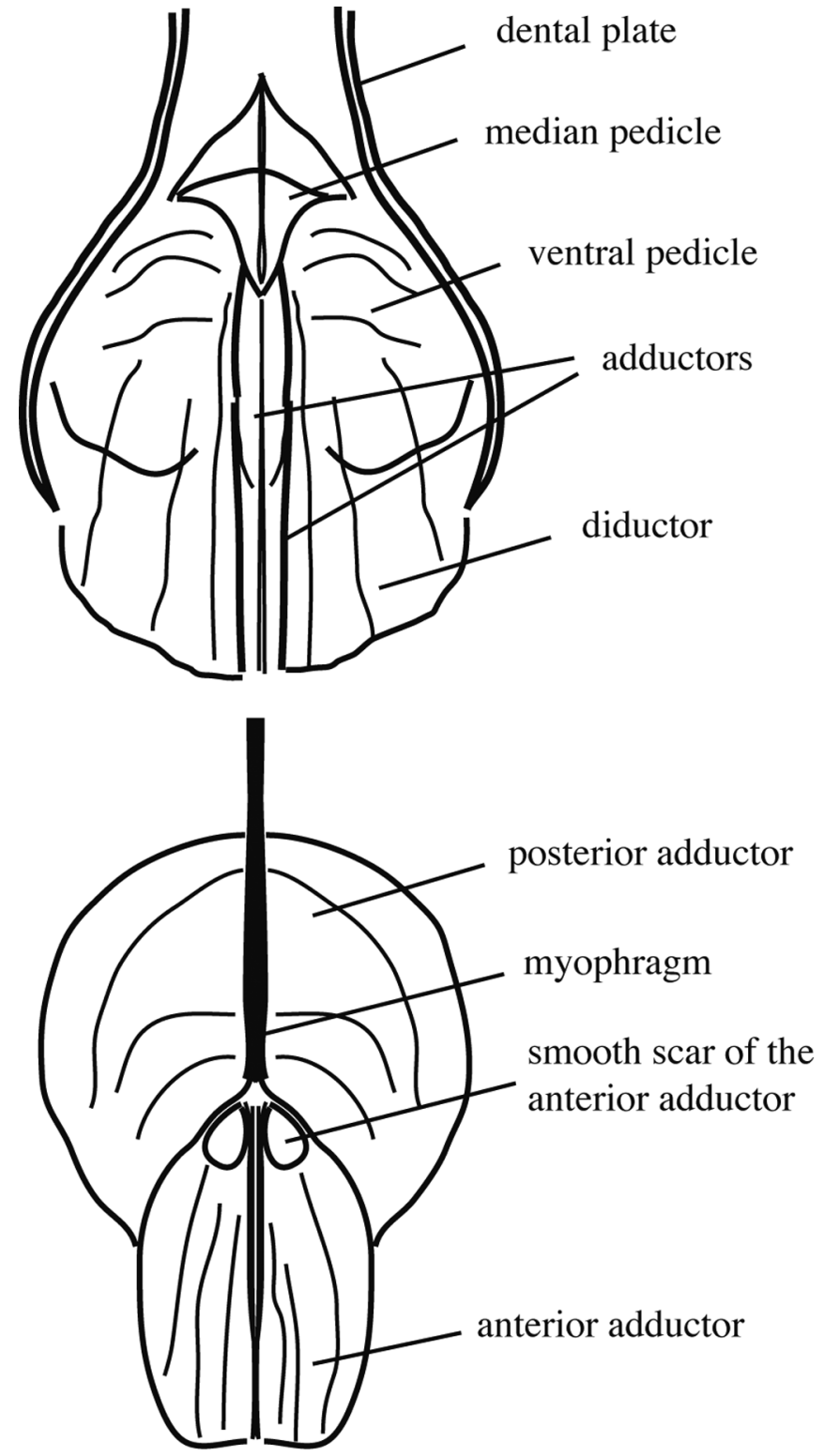

Figure 16. Cingulodermis sotoana n. sp. Camera lucida, slightly idealized, very enlarged drawings of the ventral (above) and dorsal (below) muscle fields, based mainly on internal moulds DPO 34112, 127831, and 127835.

holotype: 1.11), with rounded cardinal extremities and hinge narrower than maximum width (hinge width ca. $67 \%$ of maximum width); greatest width a little behind midlength; greatest height at the first third of length.

Pedicle valve elliptical to subpentagonal outline, strongly convex, very high; greatest height in the posterior third; strong, incurved beak overhanging the cardinal area; apical angle up to $100^{\circ}$; ventral interarea high, relatively flattened, apsacline to catacline, 3-4 times wider than high (Fig. 17a4-a5, b2, b4, c3, $\mathrm{c5}, \mathrm{d} 1, \mathrm{f} 4)$; delthyrium wide, up to a third of the interarea width, bounded by two thin delthyrial plates not fused into a deltidium. Brachial valve elliptical to subpentagonal outline, gently and evenly convex, $60 \%$ as high as the ventral valve, with greatest height at midlength; dorsal interarea almost flat, low, anacline, 
with a large, open nothothyrium provided by thin, marginal chilidial plates; dorsal beak curved, overhanging the cardinal area.
Shell surface smooth with rounded, subdued, relatively wide ventral sinus and dorsal fold, both starting ahead of the umbon-

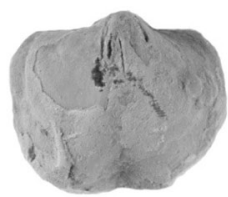

a1

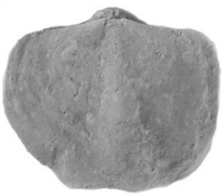

a2

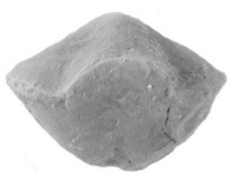

a3

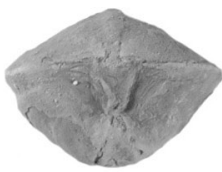

a4

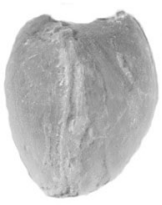

b4

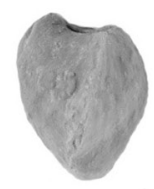

a5

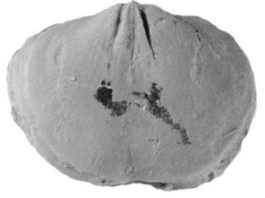

b1

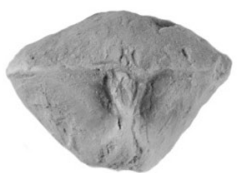

b2

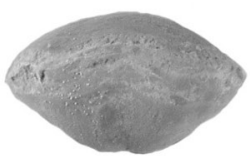

b3

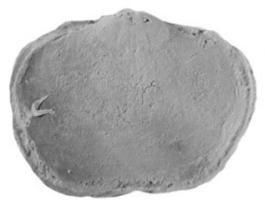

b5

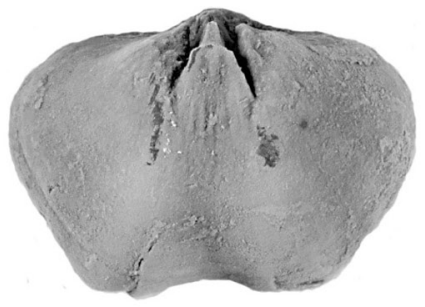

$\mathrm{c} 1$

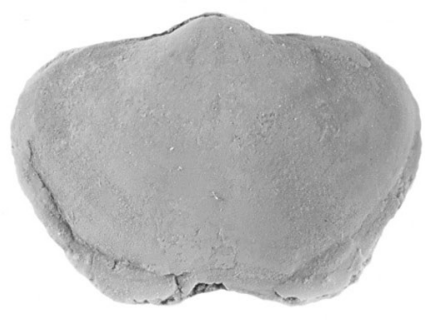

c2

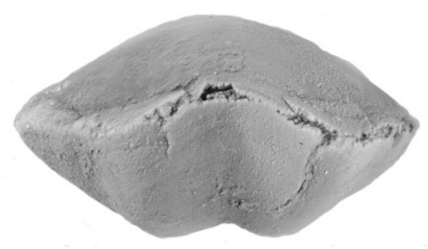

c4

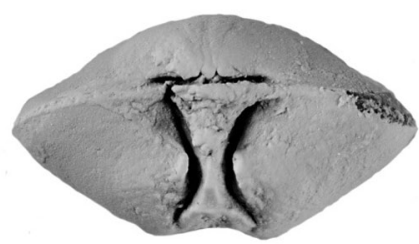

c5

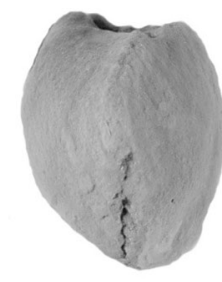

d1

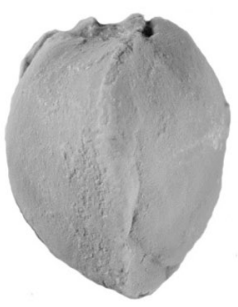

c3

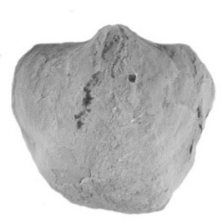

f1

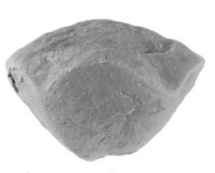

f2

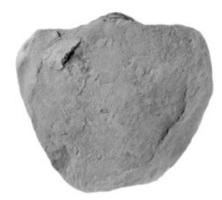

f3

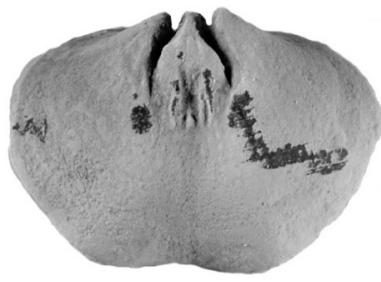

d2

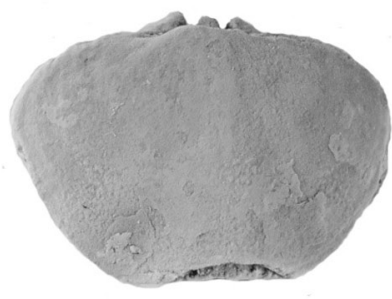

d3

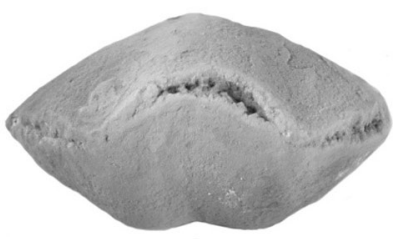

d4

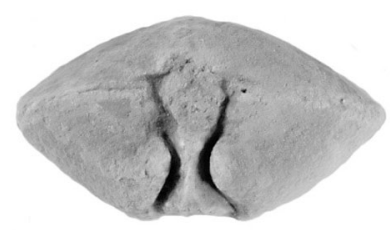

d5

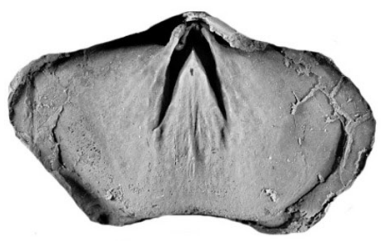

e

\section{$5 \mathrm{~mm}$}

Figure 17. Cingulodermis sotoana n. sp. a1-a5: Holotype DPO 127834, ventral, dorsal, anterior, posterior, and lateral views; b1-b5: ventral, posterior, anterior, dorsal, and lateral views of a complete internal mould, DPO 34112, showing in b2 the parallel, separate crural plates; c1-c5: ventral, dorsal, lateral, anterior, and posterior views of a pyritized, complete internal mould DPO 127831; d1-d5: lateral, ventral, dorsal, anterior, and posterior views of a nearly complete, pyritized, internal mould DPO 127835; e: pyritized internal ventral mould, DPO 127844; f1-f4: Paratype DPO 127833, ventral, anterior, dorsal, and lateral views. 
al region (width of sinus and fold greater than $1 / 3$ of the shell width); anterior commissure uniplicate; antero-lateral commissures turned up to the dorsal valve. Growth lamellae strong, few, irregularly spaced, with numerous intervening, finer growth lines. Radial capillae, surficial pits or spines lacking.

Dental plates, strong; dental flanges convergent, connected by apical callus (Fig. 17e); ventral adminicula divergent, distally curving more or less one to another, partially bounding the muscle field. Ventral muscle field clearly impressed into the shell; adductor scars, oval, flat, long, narrow, raised, bounded both by flabellate, sub-triangular diductors prolonged well ahead of the distal ends of the dental plates, and by large oval ventral pedicle scars (Fig. 16). The apical callus form, behind the adductor field, a triangular, slightly elevated platform supporting the median pedicle adjustors (Figs 16, 17b1, c1, d2, e). Cardinal process small, simple, not striate. Short, sub-parallel incisions corresponding to the crural plates, visible on well-preserved internal moulds in the immediate proximity of hinge (Fig. 17b2, c5); dorsal muscle field slightly impressed, short, divided by a thin myophragm, constituted by an anterior, subtrapezoidal adductor pair scar and a posterior, reniform adductor pair scar (Fig. 16).

Table 6. Measurements of Cingulodermis sotoana.

\begin{tabular}{|l|c|c|c|c|c|}
\hline \multicolumn{1}{|c|}{ DPO } & $\mathrm{L}$ & $\mathrm{w}$ & $\mathrm{t}$ & $\mathrm{w} / \mathrm{L}$ & $\mathrm{t} / \mathrm{L}$ \\
\hline Holotype 127834 (Fig. 17a1-a5) & 6.6 & 7.3 & 5 & 1.11 & 0.76 \\
\hline Paratype 127833 (Fig. 17f1-f4) & 6.7 & 7 & 4.9 & 1.04 & 0.73 \\
\hline 34112 (Fig. 17b1-b5) & 6.6 & 8.6 & 5 & 1.30 & 0.76 \\
\hline 127831 (Fig. 17c1-c5) & 9.5 & 13.7 & 7.6 & 1.44 & 0.80 \\
\hline 127832 & 5.9 & 6.6 & 4.5 & 1.12 & 0.76 \\
\hline 127835 (Fig. 17d1-d5) & 9.4 & 12.6 & 7 & 1.34 & 0.74 \\
\hline 127840 & 4 & 4.8 & 2.6 & 1.20 & 0.65 \\
\hline 127845 & 10 & 12.5 & - & 1.25 & - \\
\hline
\end{tabular}

Discussion: Cingulodermis sotoana n. sp. co-occurs sometimes with " $P$." palentina $\mathrm{n}$. sp. in the uppermost part of the Gustalapiedra Fm., but it is larger than the latter, with well differentiated fold and sinus, and lacks both the strong, convex symphytium and the very high, curved ventral interarea of the latter species.

Eoreticularia fraterna (Barrande, 1879) is larger than C. sotoana $\mathrm{n}$. sp., less inflated, with well- differentiated sinus and fold, low interarea bounded by obtuse edges, and micro-ornamentation granulate. Internally, the crural plates do not touch the bottom of the shell and sometimes they are united to a thin median ridge.

C. sotoana n. sp. reminds us of C. columbina (Havlíček, 1959) of the Suchomasty and Acanthopyge Limestones (Eifelian) in Bohemia, Czech Republic. The former species is, however, smaller, less transverse, with hinge line narrower, cardinal extremities more rounded, and growth lamellae stronger. The specimens of C. sotoana $\mathrm{n}$. sp. show slight differences regarding the proportions and general morphology similar to those that allowed Havlíček (1959) to subdivide $C$. columbina in two subspecies, C. columbina columbina, and C. columbina asellata. Thus, the Eifelian forms of $C$. sotoana $\mathrm{n}$. sp. that occur in the La Loma Mb. of the Gustalapiedra Fm. below the sandstones of the Man $\mathrm{Mb}$. (of upper Eifelian age) are larger and more transverse than those occurring in the La Pedrosa Mb, in the upper part of the Gustalapiedra Fm. (of lower to middle Givetian age). In addition, the younger forms have a well developed ventral sinus and dorsal fold. To date, the available samples of $C$. sotoana $\mathrm{n}$. sp. are too small to allow a further taxonomic splitting of the Palentian taxon.

Order TEREBRATULIDA Waagen, 1883 Suborder TEREBRATULIDINA Waagen, 1883

Superfamily Stringocephaloidea King, 1850

Family Stringocephalidae King, 1850

Genus Parastringocephalus Struve, 1965

Type-species: Strygocephalus dorsalis d'Archiac \& de Verneuil, 1842.

\section{Parastringocephalus cf. dorsalis (D'Archiac \& de Verneuil, 1842) Figs 3, 18}

Material: One single, bivalved, slightly crushed, surficially exfoliated specimen, DPO 126538, from the locality $\alpha-358$, ca. $190 \mathrm{~m}$ East of the Águila Peak (1,488 m), high in the western slope of the Man Creek valley, south of La Abadía de Lebanza (Fig. 2); limestones of the lower part of the Cardaño Fm. (middle Givetian) (Fig. 3).

Descriptive notes: Shell of medium size $(\mathrm{L}=54 \mathrm{~mm} ; \mathrm{w}=72.5 \mathrm{~mm}$; $\mathrm{t}=38 \mathrm{~mm}$ ), ventribiconvex, wider than long $(\mathrm{w} / \mathrm{L}=1.36)$, of spiriferoid, subpentagonal outline with rounded cardinal extremities (Figs. 18a1-a2). Hinge narrower than maximum width. Greatest width slightly anterior to midlength, maximum thickness at midlength. Pedicle valve with a strongly marked, relatively narrow sulcus (ca. $30 \%$ of the shell width at the anterior margin), with a flattened bottom, bounded by rounded ridges, extending from umbo to anterior (Fig. 18a1, a3). Beak erect, asymmetrical (Fig. 18a2, a4); apical angle, obtuse; beak ridges, strong. Ventral interarea high, concave, orthocline, transversally striated, strongly bounded; delthyrium broad; traces of an apical deltidium pierced by a small circular foramen. Dorsal interarea inconspicuous; dorsal beak strongly curved, hidden into the delthyrial cavity. The brachial valve bears a very low, indistinct, medially depressed fold, bounded by weak furrows (Fig. 18a2-a3). Anterior commissure, parasulcate. The shell surface of the available specimen has experienced intense abrasion, but some relatively well-preserved shell portions show a finely striate radial micro-ornamentation crossed by closely spaced, slightly undulating growth lines. Shell substance, densely endopunctate. The wearing off of the test reveals the occurrence of strong, internal median septa in both valves.

Remarks: The type-species of Parastringocephalus, $P$. dorsalis (d'Archiac \& de Verneuil, 1842) is very close to the Palentian form in proportions, outline and medial differentiation of shell. That species has usually been cited as 


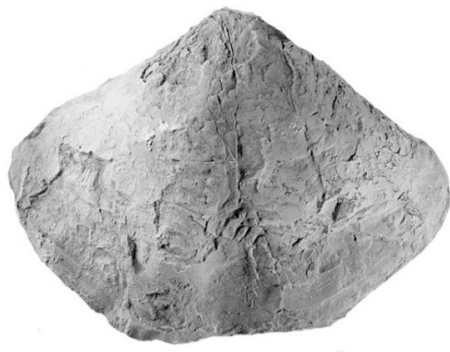

a1

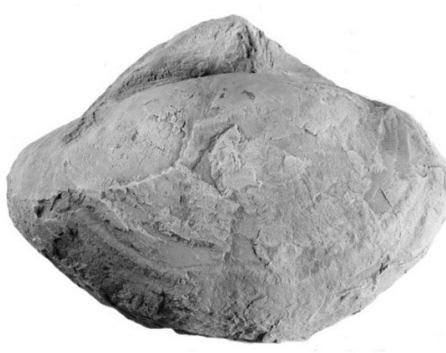

a2

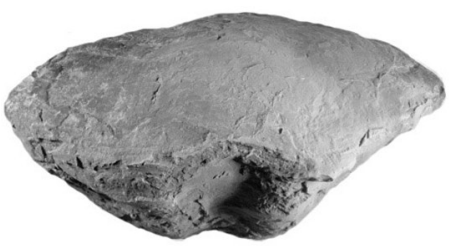

a3

Figure 18. Parastringocephalus cf. dorsalis (d'Archiac \& de Verneuil, 1842). a1-a4: ventral, dorsal, anterior, and lateral views.

middle Givetian (current sense, i.e. below the Hermanni conodont Zone) beds in Germany (Torley, 1934; Struve, 1982a,b, 1992), France (Brice \& Loones, 2002), South China (Yang et al., 1977) and tentatively in the Dra Valley, SW Morocco (Ebbighausen et al., 2007).

Family Meganterididae Schuchert \& LeVene, 1929 Subfamily Adreninae Boucot (in Boucot \& Wilson, 1994)

Genus Ense Struve, 1992

Type-species: Ense andrea Struve, 1992.

Remarks: The species of the genus, formerly collectively known as "Terebratula" pumilio, have been extensively mentioned but seldom described. This situation is probably due to the surprising find of two consecutive synchronic (or nearly so) (see above) coquinas with great accumulations of "pumilio" forms (the so-called Lower, and Upper "Pumilio" horizons) in Germany, France, Morocco, and Al- geria (Lottmann, 1990a, b; Struve, 1992), and the appealing hypothesis by Lottmann $(1990 \mathrm{a}, \mathrm{b})$ that they represent mass mortality events triggered by big tidal waves, as tsunamis.

In fact the "Pumilio" horizons have been cited in dozens of scientific articles while the systematic nature of the concerned taxa has usually been avoided. Schmidt (1960) proposed that the German "pumilio" forms were young stringocephalids of unknown generic affinities. Lottmann (1990a, b) supplied interesting historical information on the original "pumilio" forms describing in broad terms the morphology and ontogeny of the Moroccan "pumilio" material, that Struve (1992) considered later as belonging to his new species Ense albertii. Lottmann (op.cit.) brought the Moroccan material near the terebratulids based on the possible occurrence of a centronelliform loop in a single specimen (op. cit., p. 43, pl. 1, fig. 12), but at the same time spread doubt by asserting the impunctate nature of his material (preservation problem?). Struve (1992) dealt with the systematic study of the species-group, unfortunately in too concise terms, although he formally proposed the new genus Ense, integrated by the type-species, E. andrea n. sp. and by E. albertii n. sp. and E. pumilio (F.A. Roemer, 1855), the latter considered as a doubtful species because of the lack of new data after its first, old-fashioned description. This author admitted the terebratulid nature of the "pumilio" species-group based on the occurrence of a centronelliform loop in a specimen of Ense albertii (Struve, 1990: 370). Moreover, considering the external form of shell, close to Paranaia Clarke, 1913, Struve (op.cit.) included Ense in the Subfamily Mutationellinae Cloud, 1942. According to the observations of the preceding authors and the occurrence in the Palentian collection of Ense of both endopunctae and a centronelliform dorsal loop (see below), the terebratulid nature of the taxon is irrefutable. However, the paucicostate ornamental pattern of Ense is closer to the taxa of the Subfamily Adreninae Boucot (in Boucot \& Wilson, 1994), with which the discussed genus is grouped herein, than that of Mutationellinae. Adreninae should have a dorsal sulcus and a ventral fold as contrasted with the mutationellids. In particular Cydimia Chatterton, 1973, provided with dental plates and a septalium supported on a median septum, is very close to Ense. The former genus differs from Ense mainly in the rostrate deltidium and weaker dorsal median costa.

\section{Ense andrea Struve, 1992} Figs 2, 19-21

\section{Ense andrea n. sp.; Struve, p. 613.}

Material: 16 very well preserved specimens, DPO 127853127862, 127876-127881 another 11 generally incomplete, damaged specimens, DPO 127863-127870, 127873-127875, and a coquina fragment, with hundreds or possibly thousands of specimens, DPO 127871. This material comes from marly limestones of the base of the Cardaño Fm. (middle Givetian) (Fig. 3), ca. 

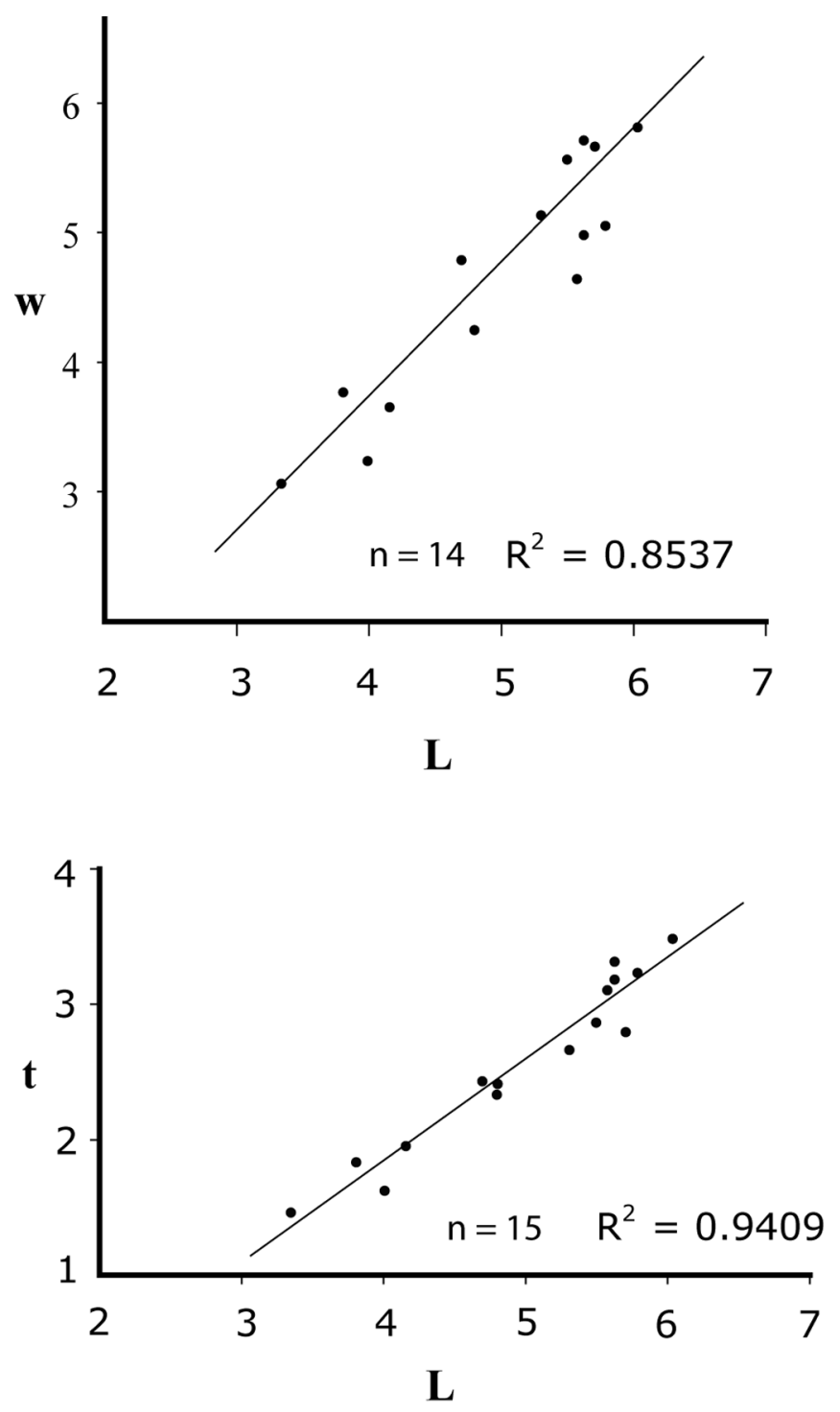

Figure 19. Ense andrea Struve, 1992. Length/width (L/w) and Length/thickness (L/t) dispersion diagrams.

$130 \mathrm{~m} \mathrm{SW}$ of La Pedrosa saddle (W Polentinos village, Cervera de Pisuerga, Province of Palencia), locality $\alpha-36$ (Fig. 2).

Description: Shell small (up to $6 \mathrm{~mm}$ length), thin (average $\mathrm{t} / \mathrm{L}=0.51$ for 15 measured specimens), either longer than wide, as long as wide, or wider than long (on 15 well preserved specimens, 9 are transverse and 5 longer than wide; average $\mathrm{w} / \mathrm{L}=0.95$ ) (Fig. 19), brachythyrid, with rounded cardinal extremities, subcircular to sub-pentagonal outline, ventri-biconvex, rostrate. Greatest width at midlength. Pedicle valve strongly convex in both transversal and longitudinal view; greatest height at midlength. Suberect (in younger individuals) to incurved beak standing out from the hinge margin; rounded beak ridges; obtuse apical angle. Low, slightly curved, apsacline to orthocline interarea; hypothyrid, circular foramen bounded by basally conjunct deltidial plates. Brachial valve weakly and evenly convex in young individuals; in adults the shell is flattened to weakly convex to ca. $2 / 3$ of length, then it curves strongly to the com-
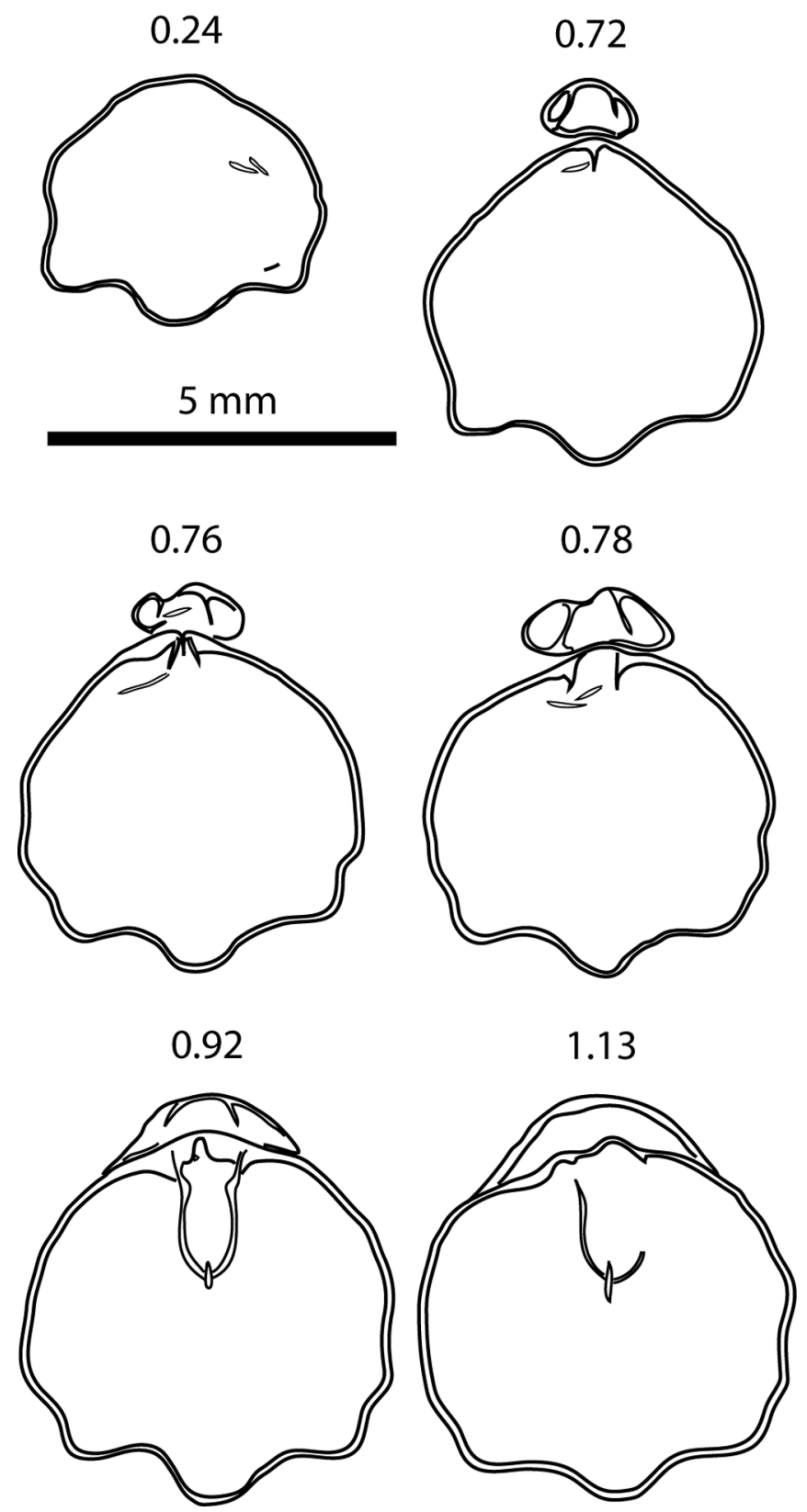

Figure 20. Ense andrea Struve, 1992. Camera lucida drawing of the serial sections of specimen DPO 127855. Distances in mm measured from the tangent to dorsal valve parallel to the commissure plane, ventralwards.

missure; greatest height in the anterior portion; dorsal beak hidden below deltidium.

In young individuals (less than $2 \mathrm{~mm}$ length) the shell is smooth (brephic stage). But from ca. $3 \mathrm{~mm}$ length and furthermore on, a paucicostate ornamentation composed by up to 8-9 strong, rounded, simple to bifurcating costae develops. In adult specimens, the umbones (representing the brephic stage of the shell growth) are smooth, ornate with only very faint growth lines. Costae extend from the first third of length to anterior; they are very weak near the umbonal region but become rapidly stronger afterwards, clearly crenulating the anterior margin. 


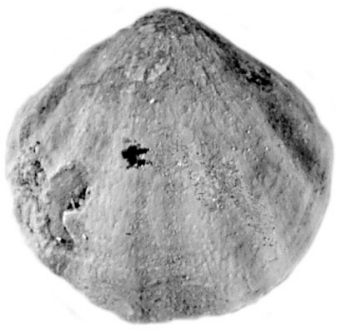

a1

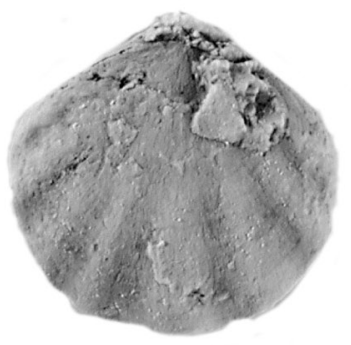

a2

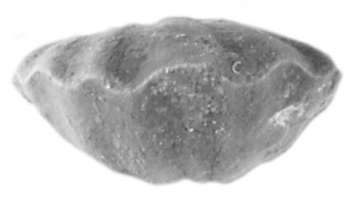

a3

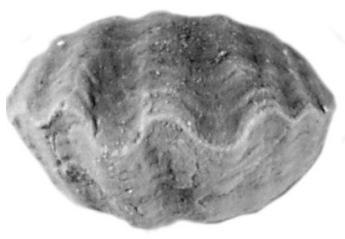

d1

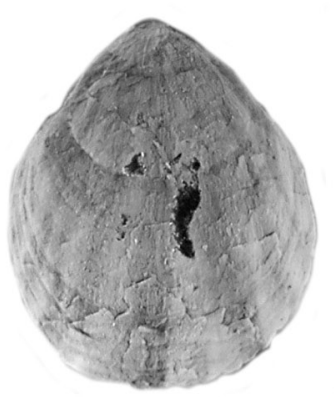

d2
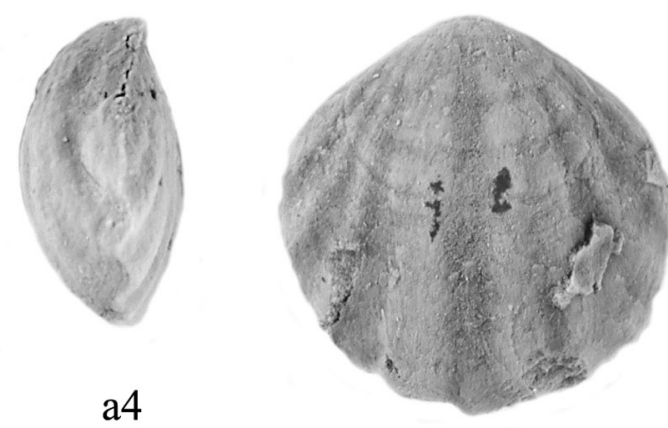

b1

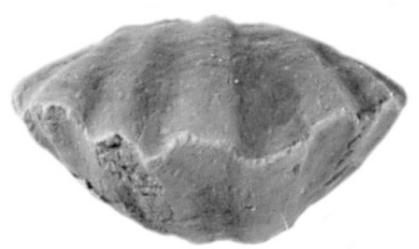

b4
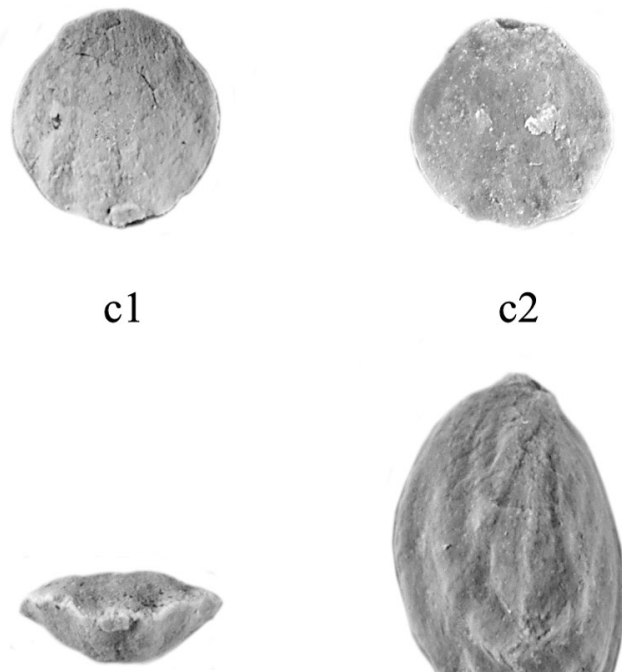

c3

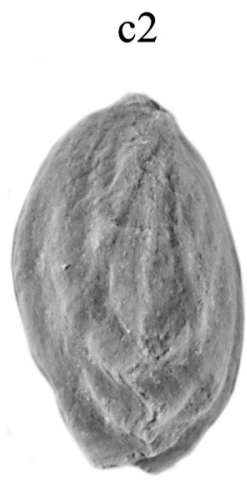

e2

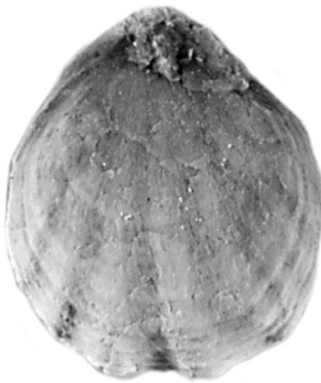

d3

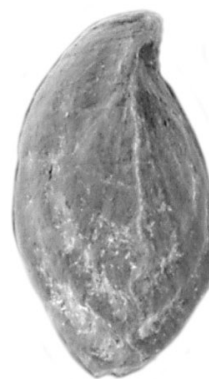

d4

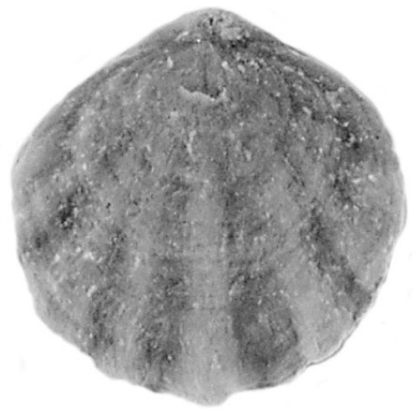

b2
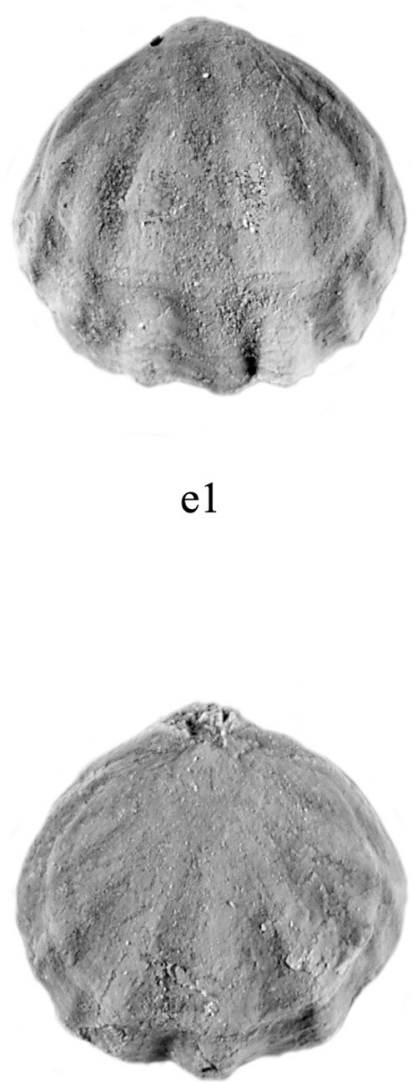

e3

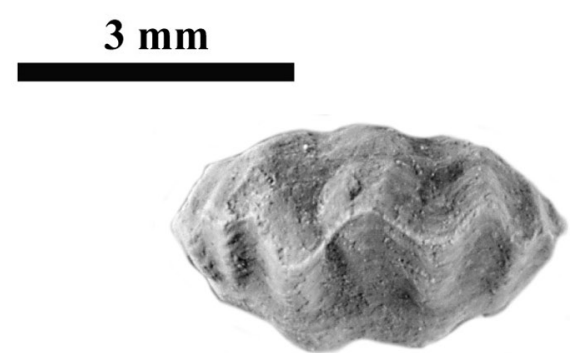

e4 
Pedicle valve with 2 median costae and up to 3-4 pairs of lateral costae; median costae stronger than the lateral, situated at a higher level, and with a wide, deep, concave to slightly convex interspace; lateral interspaces, concave, slightly wider than costae; one or two of the posterior pairs of costae, obsolescent; in a single specimen (DPO 127880) the bottom of the median ventral sulcus becomes strongly convex, turning in fact into a low, median costa, starting ahead and in a slightly lower level than its neighbours. Brachial valve with a median, strong costa situated in the bottom of a faint median sinus, and up to 4-5 lateral pairs of costae, the posterior obsolescent; median costa stronger than laterals, separated from them by wider and deeper radial furrows. Commissure crenulated, faintly unisulcate.

Growth lamellae, strong, irregularly spaced, crowded at the anterior; finer and numerous growth lines in between. Shell substance densely and minutely endopunctate.

Dental plates small, thin, diverging both ventro-dorsal- and anteriorly. Hinge plates forming a septalium supported by a low, thin, short median septum. Loop centronelliform, provided with a vertical median plate, extending to near midlength (Fig. 20).

Discussion: The original division of Ense into species is based, according to Struve (1992), on the percent of costate to smooth shells in the Lower and Upper "Pumilio" coquinas. The type-species, E. andrea Struve, 1992, would differ from $E$. albertii Struve, 1992 in the occurrence of more than 90 percent of adult specimens being weak to moderately costate, and only ca. 10 percent with strongly costate shells, developing even a clear ventral sinus and a dorsal fold. In turn, in E. albertii ca. $90 \%$ of adult specimens would be smooth and only a $10 \%$ weakly to moderately costate, with weak although noticeable ventral sinus and dorsal fold. The Palentian sample is composed mainly of more or less costate adult shells, and only the younger specimens are smooth. Slight differences between the Spanish and the German/Moroccan forms would be the more variable outline of the former and the occurrence of a linear cardinal process in the latter (according to Struve 1992, p. 612) that has not been evidenced yet on the Palentian material.

\section{ADDITIONAL REMARK}

This work will be orally presented in the XXVI Jornadas de la Sociedad Española de Paleontología, in Lisboa, July 2010. A short Spanish résumé would be included in the meeting Abstracts.

\section{ACKNOWLEDGEMENTS}

This paper is a part of the IGCP Project 499: "Evolution of the ecosystems and climates during the Devonian" and has been fi- nanced by the Spanish Project MEC-05-CGL 2005-03715 "Fases de desarrollo de asociaciones de corales y estromatoporoideos en el Devónico inferior de la Cordillera Cantábrica (NO de España) y relación de estos sucesos con eventos geo-biológicos" and FEDER funds. Thanks are due to Drs. Denise Brice, of the Université Catholique de Lille, France, Art Boucot, of the Oregon State University, Corvallis, Oregon, USA and Robert B. Blodgett, Anchorage, Alaska, USA, who have read a first draft of the manuscript and provided many useful suggestions to the author. Many thanks are due to the last two colleagues, Drs. A. Boucot and R.B. Blodgett for the complete and detailed revision final of the manuscript.

\section{REFERENCES}

Adrichem Boogaert, H.A. van 1965. Conodont-bearing formations of Devonian and Lower Carboniferous age in northern Leon and Palencia (Spain). Leidse Geologische Mededelingen, 31, 165-178.

Adrichem Boogaert, H.A. van 1967. Devonian and Lower Carboniferous conodonts of the Cantabrian Mountains (Spain) and their stratigraphic application. Leidse Geologische Mededelingen, 39, 129-192.

Alonso, J.L., Marcos, A. \& Suárez, A. 2009. Paleogeographic inversion resulting from large out of sequence breaching thrusts: The León Fault (Cantabrian Zone, NW Iberia). A new picture of the external Variscan Thrust Belt in the Ibero-Armorican Arc. Geological Acta, 7, 451-479.

Archiac, E.J.A.D. d' \& Verneuil, E. de 1842. On the fossils of the older deposits in the Rhenish provinces; preceded by a general survey of the fauna of the Palaeozoic rocks and followed by a tabular list of the organic remains of the Devonian System in Europe. Geological Society of London Transactions, 6, 303-413.

Balinski, A. 1979. Brachiopods and conodonts from the Frasnian of the Debnik Anticline, southern Poland. Palaeontologia Polonica, 39, 3-95.

Barrande, J. 1879. Système silurien du centre de la Bohême. Ière Partie. Recherches Paléontologiques, vol. 5. Classe des Mollusques: Ordre des Brachiopodes. Published by the author, Paris, $226 \mathrm{pp}$.

Becker, R.T. \& House, M.R. 1994. International Devonian goniatite zonation, Emsian to Givetian, with new records from Morocco. Courier Forschungsinstitut Senckenberg, 169, 79-135.

Becker, R.T., Bockwinkel, J., Ebbighausen, V., Aboussalam, S.Z., El Hassani, A. \& Nübel, H. 2004. Lower and Middle Devonian stratigraphy and faunas at Bou Tserfine near Assa (Dra Valley, SW Morocco). In: Devonian neriticpelagic correlation and events in the Dra Valley (Western Anti-Atlas, Morocco) (Ed. A. El Hassani). International Meeting on Stratigraphy, Rabat. Documents de l'Institut Scientifique, 19, 90-100.

Figure 21. Ense andrea Struve, 1992. a1-a4: specimen DPO 127858, ventral, dorsal, anterior, and lateral views; b1-b4: specimen DPO 127877, ventral, dorsal, lateral, and anterior views; c1-c3: ventral, dorsal, and anterior views of a partially broken, young specimen DPO 127862; d1-d4: specimen DPO 127853, anterior, ventral, dorsal, and lateral views; e1-e4: specimen DPO 127854, ventral, lateral, dorsal, and anterior views. 
Biernat, G. 1959. Middle Devonian Orthoidea of the Holy Cross Mountains and their ontogeny. Palaeontologia Polonica, 10, 1-78.

Binnekamp, J.G. 1965. Lower Devonian brachiopods and stratigraphy of North Palencia (Cantabrian Mountains, Spain). Leidse Geologische Mededelingen, 33, 1-62.

Boucot, A.J., Johnson, J.G. \& Staton, R.D. 1964. On some atrypoid, retzioid, and athyridoid Brachiopoda. Journal of Paleontology, 38, 805-822.

Boucot, A.J. \& Wilson, R.A. 1994. Origin and early radiation of terebratuloid brachiopods: thoughts provoked by Prorensselaeria and Nanothyris. Journal of Paleontology, 68, 1002-1025.

Brice, D. \& Loones, C. 2002. Nouvelles données sur des brachiopods Cyrtospiriferidae, Reticulariidae, Uncitidae et Stringocephalidae du Dévonien de Ferques (BoulonnaisFrance). Annales de la Société Géologique du Nord, 9 (2 ser.), 91-110.

Brice, D. \& Ouali Mehadji, A. 2009. Découverte d'une "faune naine" de Pentamerida (Brachiopoda dévoniens) à Gara Djebilet (flanc sud du Bassin de Tindouf) en Algérie. Annales de la Société Géologique du Nord, 165, 69-77.

Bronn, H.G. 1862. Die Klassen und Ordnungen der Weichthiere (Malacozoa), vol. 3(1). C.F. Winter'sche Verlagshandlung. Leipzig \& Heidelberg, 518 pp.

Brouwer, A. 1964. Deux faciès dans le Dévonien des Montagnes Cantabriques méridionales. Breviora Geologica Asturica, 8, 3-10.

Bultynck, P. \& Gouwy, S. 2008. Reference sections for the Middle Givetian Substage. SDS Newsletter, 23, 21-31.

Bultynck, P. \& Hollard, H. 1980. Distribution comparée de Conodontes et Goniatites dévoniens des plaines du Dra, du Ma'der et du Tafilalt (Maroc). Aardkundige Mededelingen, 1, 1-73.

Carter, J.L., Johnson, J.G., Gourvennec, R. \& Hou, H.-F. 1994. A revised classification of the spiriferid brachiopods. Annals of Carnegie Museum, 63, 327-374.

Clarke, J.M. 1913. Fósseis devonianos do Paraná. Monographia do Serviço Geológico e Mineralógico do Brasil, 1, $\mathrm{xx}+353 \mathrm{pp}$.

Chatterton, B.D.E. 1973. Brachiopods of the Murrumbidge Group, Taemas, New South Wales. Bulletin of Mineral Resources, Geology \& Geophysics, 137, 1-146.

Cloud, P.E. 1942. Terebratuloid brachiopoda of the Silurian and Devonian. Geological Society America, Special Papers, 38, $182 \mathrm{pp}$.

Copper, P. 1996. Davidsonia and Rugodavidsonia (new genus), cryptic Devonian Atrypid brachiopods from Europe and South China. Journal of Paleontology, 70, 588-602.

Copper, P. 2002. Atrypida. In: Treatise on Invertebrate Paleontology (Ed. R.L. Kaesler), H 4, Rhynchonelliformea (part) revised, 1377-1474.

Davidson, T. 1882. A Monograph of the British Fossil Brachiopoda, vol. 5 part 1. Devonian and Silurian Supplements. Palaeontographical Society Monograph, London, 134 pp.

Drot, J. 1961. Quelques formes de Brachiopodes Givétiens du Drâa (Maroc présaharien) peu comunes en Afrique du Nord. Notes du Service géologique du Maroc, 20, 59-68.
Drot, J. 1964. Rhynchonelloidea et spiriferoidea SiluroDévoniens du Maroc pré-saharien. Notes et Mémoires du Service Géologique, 178, 1-286.

Ebbighausen, V., Bockwinkel, J., Becker, T.R., Aboussalam, S.Z., Bultynck, P., El Hassani, P. \& Nübel, H. 2004. Late Emsian and Eifelian stratigraphy at Oufrane (Tata region, eastern Dra Valley, Morocco). In: Devonian neriticpelagic correlation and events in the Dra Valley (Western Anti-Atlas, Morocco) (Ed. A. El Hassani). International Meeting on Stratigraphy, Rabat. Documents de l'Institut Scientifique, 19, 44-52.

Ebbighausen, V., Becker, R.T., Bockwinkel, J. \& Aboussalam, Z.S. 2007. Givetian (Middle Devonian) brachiopod-goniatite-correlation in the Dra valley (Anti-Atlas, Morocco) and Bergisch Gladbach-Paffrath Syncline (Rhenish Massif, Germany). In: Devonian Events and Correlations (Eds. R.T. Becker \& W.T. Kirchgasser). Geological Society Special Publications, 278, 157-172.

El Hassani, A. (editor) 2004. Devonian neritic-pelagic correlation and events in the Dra Valley (Western Anti-Atlas, Morocco). International Meeting on Stratigraphy, Rabat. Documents de l'Institut Scientifique, 19, 1-100.

Ellwood, B.B., García-Alcalde, J.L., El Hassani, A., Hladil, J., Soto, F.M., Truyols-Massoni, M., Weddige, K. \& Koptikova, L. 2006. Stratigraphy of the Middle Devonian boundary: formal definition of the susceptibility magnetostratotype in Germany with comparisons to sections in the Czech Republic, Morocco and Spain. Tectonophysics, 418, 31-49.

Frederiks, G.N. 1924. Paleontologitcheskie ztoudy, 2: O verkhne kamennougolnykh spiriferidakh Ourala (Paleontological studies. 2: On Upper Carboniferous spiriferids from the Urals). Izvestyia geologicheskogo Komiteta, 38, 295-324 [in Russian].

García-Alcalde, J.L. 1999. Braquiópodos hercínicos del Eifeliense superior (Devónico Medio) del Dominio Palentino (N de España). Temas Geológico-Mineros ITGE, 26, 599-604.

García-Alcalde, J.L. 2000. Terebratulida. In: Brice, D. et al. Brachiopoda. SDS Fossil groups important for boundary definition (Ed. P. Bultynck), Courier Forschungsinstitut Senckenberg, 220, 79-81.

García-Alcalde, J.L. 2009. Palentiella palentina n. g. n. sp. (Braquiópodo Camarotoechioidea) del Eifeliense superior de la región Palentina (Cordillera Cantábrica oriental, N de España). Revista Española de Paleontología, 24, 79-92.

García-Alcalde, J.L. \& Soto, F. 1999. El límite Eifeliense/ Givetiense (Devónico Medio) en la Cordillera Cantábrica (N de España). Revista Española de Paleontología, $\mathbf{n}^{\mathbf{0}}$ extra homenaje J.Truyols, 43-56.

García-Alcalde, J.L. \& Truyóls-Massoni, M. 2000. Iberian Massif. Cantabrian Mountains. In: Subcommission on Devonian Stratigraphy. Recognition of Devonian series and stage boundaries in geological areas. Devonian chronostratigraphy of Spain (Ed. P. Bultynck). Courier Forschungsinstitut Senckenberg, 225, 132-136.

García-Alcalde, J.L., Montesinos, J.R., Truyols-Massoni, M., García-López, S., Arbizu, M. \& Soto, F. 1988. El Silúrico 
y el Devónico del Dominio Palentino (NO de España). Revista de la Sociedad Geológica de España, 1, 7-13.

García-Alcalde, J.L., Arbizu, M., García Lopez, S., Leyva, F., Montesinos, R., Soto, F. \& Truyols-Massoni, M. 1990a. Devonian stage boundaries (Lochkovian/Pragian, Pragian/ Emsian, and Eifelian/Givetian) in the Cantabric region (NW Spain). Neues Jahrbuch Paläontologie Abhandlungen, 180, 177-207.

García-Alcalde, J.L., Montesinos, J.R., Truyols-Massoni, M., García-López, S., Arbizu, M.A. \& Soto, F. 1990b. The Palentine Domain (Palentian Zone). In: Pre-Mesozoic Geology of Iberia (Eds. R.D. Dallmeyer \& E. MartínezGarcía). Elsevier, 20-23.

García-Alcalde, J.L., Arbizu, M. \& Truyols-Massoni, M. 2001. Extinciones masivas en el Devónico. In: La Era Paleozoica. El desarrollo de la vida marina. Homenaje al Profesor Jaime Truyols, (Eds. J.A. Gámez \& E. Liñán). Institución "Fernando el Católico", Diputación de Zaragoza, 125-145.

García-Alcalde, J.L. (coordinator), Carls, P., Pardo Alonso, M.V., Sanz López, J., Soto, F., Truyols-Massoni, M. \& Valenzuela-Ríos, J.I. 2002. Devonian. In: The Geology of Spain (Eds. W. Gibbons \& T. Moreno). The Geological Society, London, 67-91.

George, T.N. 1931. Ambocoelia Hall and certain similar British Spiriferidae. Geological Society of London, Quarterly Journal, 87, 30-61.

Gozalo, R. \& Sánchez de Posada, L.C. 1998. El género Franklinella (Ostracoda) en la sección de Collado de Polentinos (Devónico del Dominio Palentino, Cordillera Cantábrica). Revista Española de Paleontología, 13, 235-242.

Gozalo, R., Arbizu, M. \& Montesinos, J.R. 1990. Nota preliminar sobre la fauna de ostrácodos y trilobites del Devónico Medio y Superior, en el Dominio palentino. In: Actas de Paleontología (IV Jornadas de Paleontologia, Salamanca, 1988) (Eds. J. Civis-Llovera \& FloresVillarejo), 211-216.

Gürich, G. 1896. Das Paleozoicum im Polnischen Mittelgebirge. Zapiski Imperatorskogo St. Petersburgskogo Mineralogicheskogo Obshchestva, (series 2) 32, 539 pp.

Hall, J. 1859. Palaeontology of New York, vol. 3, Containing descriptions and figures of the organic remains of the lower Helderberg Group and the Oriskany Sandstone. New York Geological Survey, Natural History of New York, C. van Benthuysen, Albany, 532 pp.

Hall, J. 1860. Observations on Brachiopoda. New York State Cabinet of Natural History, $13^{\text {th }}$ Annual Report, Albany, 65-75.

Havlíček, V. 1956. Ramenonozci vápencu branickych a hlubočepskyck z nejblizsího prazského okolí. Sbornik Ústředního ústavu Geologického, 22, Paleontologicky, 535-665. (in Czech with a [English summary: pp. 651-665]).

Havliček, V. 1959. Spiriferidae v Ceském Siluru a Devonu (Brachiopoda) (The Spiriferidae of the Silurian and Devonian of Bohemia). Ústředního Ústavu Geologického, Rozpravy, 25, 275 pp.

Havlíček, V. 1967. Brachiopods of the Suborder Strophomenidina in Czechoslovakia. Ústředniho ústavu Geologického, Rozpravy, 33, 235 pp.
Havliček, V. 1971. Non costate and weakly costate Spiriferidina (Brachiopoda) in the Silurian and Lower Devonian of Bohemia. Sborník Geologickych Vèd, Paleontologie, 14, 7-34.

Havlíček, V. 1987. Lower Devonian and Eifelian Atrypacea (Brachiopoda) in central Bohemia. Sbornik Geologickych Véd, Paleontologie, 28, 61-115.

Havlíček, V. 1998. Notes of validity of several Silurian and Lower Devonian genera of Atrypida (Brachiopoda) in the Prague Basin, Czech Republic. Vestnik Českého geologického ústavu, 73, 51-54.

Henn, A. 1985. Biostratigraphie und Fazies des hohen Unter-Devon bis tiefen Ober-Devon der Provinz Palencia, Kantabrisches Gebirge, N-Spanien. Göttinger Arbeiten zur Geologie und Paläontologie, 26, 1-100.

Henn, A. \& Jahnke, H. 1984. Die palentinische Faziesentwicklung im Devon des Kantabrischen Gebirges. Zeitschrift dt.geologisches Gesellschaften, 135, 131-147.

Ivanova, E.A. 1972. Osnovnyye zakonomernosti evolyutsii spiriferid (Brachiopoda) (Main features of spiriferid evolution (Brachiopoda)). Paleontologicheskii Zhurnal, 1972, 28-42 [in Russian].

Jahnke, H., Henn, A., Mader, H. \& Schweineberg, J. 1983. Silur und Devon im Arauz-Gebiet (Prov.Palencia, NSpanien). Newsletter in Stratigraphy, 13, 40-66.

Johnson, J.G. 1970. Taghanic onlap and the end of North American Devonian Provinciality. Geological Society of America Bulletin, 81, 2027-2105.

Johnson, J.G. 2006. Cyrtinoidea. In: Treatise on Invertebrate Paleontology (Ed. R.L. Kaesler). H 5, Rhynchonelliformea (part) revised, 1881-1883.

Julivert, M. 1971. L'évolution structurale de l'Arc Asturien. In: Histoire Structurale du Golfe de Gascogne". Publications de l'Institut Français du Pétrole, 1, 1-28.

King, W. 1850. A monograph of the Permian fossils of England. Palaeontographical Society Monograph, 3, 258 pp.

Kozłowski, R. 1929. Les brachiopodes gothlandiens de la Podolie polonaise. Palaeontologia Polonica, 1, 1-254.

Kullmann, J. 1960. Die Ammonoidea des Devon im Kantabrischen Gebirge (Nordspanien). Akademie Wissenschaften und Litteratur Abhandlungen Mathematisch-naturwissenchaft klasse, 1960, 1-105.

Kullmann, J. 1964. Las series devónicas y del Carbonífero inferior con ammonoideos de la Cordillera Cantábrica. Estudios Geológicos, 19, 161-191.

Lobato, L. 1977. Geología de los valles altos de los ríos Esla, Yuso, Carrión y Deva. Institución Fray Bernardino de Sahagún (Diputación Provincial de León), 192 pp.

Lottmann, J. 1990a. Die pumilio-Events (Mittel-Devon). Göttinger Arbeiten zur Geologie und Paläontologie, 44, 1-98.

Lottmann, J. 1990b. The Middle Givetian Pumilio-events a tool for high time resolution and event-stratigraphical correlation. In: Extinction events in Earth History (Eds. E.G. Kauffman \& O.H. Walliser). Lecture Notes in Earth Sciences, 30, 145-149.

Lotze, F. 1945. Zur Gliederung der Varisziden der Iberischen Meseta. Geotektonische Forschungen, 6, 78-92.

Montesinos, J.R. 1987a. Agoniatitina y Anarcestina del Devónico Medio de la Cordillera Cantábrica (Dominios 
Palentino y Asturleonés, NO de España). Cuadernos Laboratorio Xeolóxico de Laxe, 1, 99-118.

Montesinos, J.R. 1987b. Aulatornoceras (Truyolsoceras) n. subgen. (Ammonoidea, Tornoceratina) del Devónico de las cordilleras Cantábrica e Ibérica (NO y NE de España). Cuadernos Laboratorio Xeolóxico Laxe, 12, 119-126.

Montesinos, J.R. 1990. Las biozonas de ammonoideos del Devónico (Emsiense Inferior-Famenniense Inferior): crítica al sistema de clasificación zonal. Revista Española de Paleontología, 5, 3-17.

Montesinos, J.R. \& Henn, A. 1986. La fauna de Pharciceras (Ammonoidea) de la Formación Cardaño (Dominio Palentino, Cordillera Cantábrica, NO de España). Trabajos de Geología de la Universidad de Oviedo, 16, 61-76.

Montesinos, J.R. \& Sánz-López, J. 1997. Los ammonoideos de la parte superior de la Formación Cardaño (unidad del Gildar-Montó, NE de la provincia de León, España) y su aplicación a la bioestratigrafía del Devónico Superior. Revista Española de Paleontología, 12, 243-248.

Montesinos, J.R. \& Sánz-López, J. 1999. Falcitornoceras and Cheiloceras (Ammonoidea, Goniatitida) from the lower Famennian of the Iberian Peninsula and their biostratigraphic applications. Newsletter in Stratigraphy. 37, 163-175.

Mottequin, B. 2008. New observations on Upper Devonian brachiopods from the Namur-Dinant Basin (Belgium). Geodiversitas, 30, 455-537.

Muir-Wood, H.M. 1955. A History of the Classification of the Phylum Brachiopoda. British Museum (Natural History), $124 \mathrm{pp}$.

Nalivkin, D.V. 1947. Brakhiopody. In: Atlas rukovodiashchikh form iskopaemykh fauni SSSR, Tome 3, Devonskaia Sistema (Atlas of index fossil faunas of the USSRDevonian System) (Ed. D.V. Nalivkin), Vsesoiuzni Nauchnoissledovatel'skii Geologicheskii Institut (VSEGEI), Leningrad, 245 pp. [in Russian].

Oleneva, N.V. 2006. Pyramidal Spiriferids (Brachiopods) from the Middle and Upper Devonian of the Russian Plate: Morphology, Systematics, and Shell Wall Structure. Paleontological Journal, 40, 415-424.

Paulus, B. 1957. Rhynchospirifer $\mathrm{n}$. gen. im Rheinischen Devon (Rhynchospiriferinae n. subf., Brachiopoda). Senckenbergiana lethaea, 38, 62 pp.

Phillips, J. 1841. Figures and descriptions of the Palaeozoic fossils of Cornwall, Devon, and West Somerset. Geological Survey of Great Britain, Memoirs, 1, 1-231.

Pitrat, C.W. 1965. Spiriferidina. In: Treatise on Invertebrate Paleontology (Ed. R.C. Moore). H 2, 667-728.

Racheboeuf, P.R. 1981. Chonetacés (Brachiopodes) siluriens et dévoniens du Sud-Ouest de l'Europe. Mémoire de la Société Géologique et Minéralogique de Bretagne, 27, 294 pp.

Rigaux, E. 1892. Notice géologique sur le Boulonnais. Boulogne-sur-Mer, Mlle. Deligny, Libraire-Editeur, 108 pp.

Roemer, F.A. 1855. Beiträge zur geologischen Kenntniss des nordwestlichen Harzgebirges. Dritte Abtheilung. Palaeontographica, 5, 1-46.

Rodríguez-Fernández, L.R. 1994. La estratigrafía del Paleozoico y la estructura de la región de Fuentes Carrionas y áreas adyacentes (Cordillera Herciniana, NO de España). Laboratorio Xeolóxico Laxe, serie Nova Terra, 9, 1-240.

Rzhonsnitskaia, M.A. 1960. Order Atrypida. In: Osnovy Paleontologii, 7. Mshanki, Brakhiopody (Bryozoa, Brachiopoda) (Ed. Y.A. Orlov). Akademia Nauk SSSR, Moscow, 257-264 [in Russian].

Sánz-López, J., García López, S. \& Montesinos, J.R. 1999. Conodontos del Frasniense Superior y Fameniense Inferior de la Formación Cardaño (Unidad del Gildar-Montó, Dominio Palentino, Zona Cantábrica). Revista Española de Paleontología, 14, 25-35.

Sarytcheva, T.G. \& Sokolskaya, A.N. 1959. O klassifikatsin lozhnoporistykh brakhioopod (On the classification of pseudopunctate brachiopods). Akademia Nauk SSSR, Doklady (Moscow), 125, 181-184 [in Russian].

Schmidt, H. 1960. Die sogenannte "Terebratula pumilio" als Jugendform von Stringocephaliden. Paläontologisches Zeitschrift, 34, 161-168.

Schuchert, C. 1894. A revised classification of the spire bearing Brachiopoda. The American Geologist, 13, 102-107.

Schuchert, C. \& Cooper, G.A. 1931. Synopsis of the brachiopod genera of the suborders Orthoidea and Pentameroidea, with notes on the Telotremata. American Journal of Science, 22, 241-255.

Schuchert, C. \& LeVene, C. M. 1929. Brachiopoda (Generum et Genotyporum Index et Bibliographia). In: Fossilium Catalogus 1: Animalia, part 42: Brachiopoda (Ed. J.F. Pompeckj). W. Junk, Berlin, 1-140.

Smeenk, Z. 1983. Devonian trilobites of the southern Cantabrian Mountains (northern Spain) with a systematic description of the Asteropyginae. Leidse Geologische Mededelingen, 52, 383-511.

Stainbrook, M.A. 1945. Brachiopoda of the Independence Shale of Iowa. Geological Society America, Memoir, 14, 1-73.

Struve, W. 1965. Beiträge zur kenntnis devonischer brachiopoden, 14): Über Geranocephalus (Stringominus) n.subg. und verwandte. Senckenbergiana lethaea, 46, 459-472.

Struve, W. 1982a. Beiträge zur kenntnis devonischer brachiopoden, 23): Schaltier-Faunen aus dem Devon des Schwarzbach-Tales bei Ratingen, Rheinland. Senckenbergiana lethaea, 63, 183-283.

Struve, W. 1982b. The great gap in the record of marine Middle Devonian. Courier Forschungsinstitut Senckenberg, $\mathbf{5 5}, 433-448$.

Struve, W. 1990. Paläozoologie III. In: W. Ziegler, "Bericht des Direktors (für das Jahr 1989)". Natur und Museum, 120, 370-371

Struve, W. 1992. Neues zur Stratigraphie und Fauna des rhenotypen Mittel-Devon. Senckenbergiana lethaea, 71, 503-624.

Torley, K. 1934. Die Brachiopoden des Massenkalkes der Oberen Givet-Stufe von Bilveringsen bei Iserlohn. $A b$ handlungen herausgegeben von der Senckenbergischen Naturforschenden Gesellschaft, 43, 67-148.

Truyols-Massoni, M. 1989. Devonian homoctenids of the Cantabrian Zone (NW, Spain): an attempt of biozonation. Géobios, 22, 671-676.

Truyols-Massoni, M. 1999. El género Undastriatostyliolina en la Cordillera Cantábrica (NO de España). Sistemática, evo- 
lución y paleobiogeografía. Revista Española de Paleontología, $\mathbf{n}^{\mathbf{0}}$ extra. homenaje Prof. J. Truyols, 239-249.

Truyols-Massoni, M., Montesinos, R., García-Alcalde, J.L. \& Leyva, F. 1990. The Kačak-Otomari event and its characterization in the Palentine Domain (Cantabrian Zone, NW Spain). In: Extinction events in Earth History (Eds E.G. Kauffman \& O.H. Walliser). Lecture Notes in Earth Sciences, 30, 133-143.

Vandercammen, A. 1957. Révision des Reticulariinae du Dévonien de la Belgique. 2. Genre Plectospirifer A. GRABAU, 1931. Bulletin de l'Institut royal des Sciences naturelles de Belgique, 33, 1-23.

Veen, J. van 1965. The tectonic and stratigraphy history of the Cardaño area, Cantabrian Mountains, northwest Spain. Leidse Geologische Mededelingen, 35, 45-104.

Waagen, W.H. 1883. Salt Range Fossils. I. ProductusLimestone Fossils. Geological Survey of India, Memoirs, Palaeontologia Indica (series 13), 4, 391-546.

Weddige, K. 1988. Eifel conodonts. In: Ziegler, W. (ed.), 1st International Senckenberg Conference and 5th European
Conodont Symposium (ECOS V) Contributions I, Courier Forschungsinstitut Senckenberg, 102, 103-110.

Wendt, J., Kaufmann, B. \& Belka, Z. 2009. Devonian stratigraphy and depositional environments in the southern Illizi Basin (Algerian Sahara). Journal of African Earth Sciences, 54, 85-96.

Whidborne, G.F. 1893. A monograph of the Devonian fauna of South of England. 2. The fauna of the limestones of Lummaton, Wolborough, Chircombe Bridge, and Chudleigh, vol. 2, part. 3. Palaeontographical Society of London, 89-160.

Yang, D. L., Ni, S. Z., Chang, M. L. and Zhao, Y. X. 1977. Brachiopoda. In: Paleontological Atlas of Central-South China (Ed. Hubei Institution of Geology and Science et al.), Volume 2. Geological Publishing House, Beijing, 306-470 [in Chinese].

Manuscrito recibido: 14 de Abril, 2010 Manuscrito aceptado: 7 de Junio, 2010 